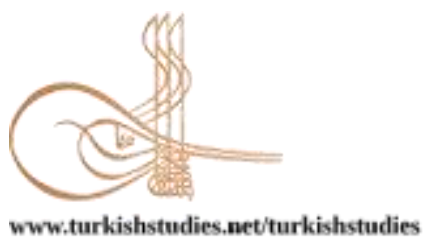

Turkish Studies

\title{
Okul Yöneticilerinin Teknoloji Liderliği Yeterlik Algıları ile Yenilik Yönetimi Yeterlikleri Arasındaki İlişsinin İncelenmesi"
}

\author{
Analysing the Relationship Between School Administrators' Perceptions of Technological \\ Leadership Competencies and Innovation Management Competencies
}

\author{
Baran Barış Yıldız ${ }^{* *}$ - Harun Tüysüz ${ }^{* * * *}$ - Mustafa Öztürk ${ }^{* * * *}$
}

\begin{abstract}
This study is a quantitative study carried out to analyse the relationship between school administrators' technology leadership competencies perceptions and innovation management with the aim of improving professional skills of school administrators in Turkey's Education Vision 2023. In this research, a comparative relational screening model, one of the quantitative research methods, was used. The population of the study consisted of 172 administrators working in public schools in district of Avc1lar, İstanbul in 20192020 academic year. The aim was to reach all the administrators in the population by not taking samples and 132 school administrators participated in this study. The data collection tools of the study were technology leadership competencies scale developed by Hacifazlioglu, Karadeniz and Dalgic (2011a) and innovation management scale developed by Bülbül (2012a) was used. Technology Leadership Efficacy Perceptions Scale and School Administrators' Innovation Management Scale in Educational Organizations; The Mann WhitneyU Test was applied to determine whether it differs according to the variable of gender, education level, branch, job title and in-service training in the field of information technologies, and the Kruskal Wallis- $\mathrm{H}$ Test to determine whether it differs according to the variable of school type. According to the results of the study, technology leadership competency perceptions of school administrators were high; innovation management competency perceptions were very high. There was no significant difference in terms of gender, education degree, subject and school type but a significant difference was found in position title and participation inservice training related to information technologies. The school principals' mean scores were significantly
\end{abstract}

\footnotetext{
* Bu çalışma 17-21 Kasım 2020'de gerçekleştirilen 11. Uluslararası Eğitim Yönetimi Forumu EYFOR-11'de bildiri olarak sunulan bildirinin gözden geçirilmiş ve genişletilmiş halidir.

*** Dr, Millî Eğitim Bakanlığı

Phd., Republic of Turkey, Ministry National of Education

ORCID 0000-0003-1247-3158

bbariş_yildiz@windowslive.com

**** * Dr, Millî Eğitim Bakanlığı

Phd., Republic of Turkey, Ministry National of Education

ORCID 0000-0002-5670-7430

harun_54@hotmail.com

**** Uzman, Millî Eğitim Bakanlı̆̆

Phd., Republic of Turkey, Ministry National of Education

ORCID 0000-0002-2986-9055

mustafaozturk19805534@hotmail.com

Cite as/ Atıf: Yıldız, B. B., Tüysüz, H. \& Öztürk, M. (2021). Okul yöneticilerinin teknoloji liderliği yeterlik algıları ile yenilik yönetimi yeterlikleri arasındaki ilişkinin incelenmesi. Turkish Studies, 16(3), 1087-1108. https://dx.doi.org/10.7827/TurkishStudies.50790

Received/Geliş: 08 April/Nisan 2021

Accepted/Kabul: 20 June/Haziran 2021

Checked by plagiarism software

Published/Yayın: 25 June/Haziran 2021

CC BY-NC 4.0
} 
higher than deputy principals and the average scores of school administrators, participated in-service training related to information technologies were significantly higher than school administrators that didn't participate. There was a positive and high correlation between school administrators' perceptions of technological leadership competencies and innovation management competencies.

Structured Abstract: This study is a quantitative study carried out to analyse the relationship between the School Administrators' Technology Leadership Competencies Perceptions and Innovation Management

Competencies, with the aim of improving the professional skills of school administrators in Turkey's Education Vision 2023. In this research, a comparative relational screening model, one of the quantitative research methods, was used.

\section{Method}

The aim of the study was to determine the relationship between technology leadership competencies perceptions and innovation management competencies of school administrators working in public primary, secondary and high school in the Ministry of National Education, 2019-2020 academic year in the district of Avcilar, İstanbul and to determine the significant differences according to some demographic variables.

The population of the study consisted of 172 administrators working in the public primary, secondary and high school in the Ministry of National Education, 2019-2020 academic year in the district of Avc1lar in İstanbul. In this study, the aim was to reach 172 participants in the universe by not taking samples and 132 school administrators participated in this research.

The data collection tools of the study were Technology Leadership Competencies Scale developed by Hacifazlioglu, Karadeniz, and Dalgic (2011a) and the "Innovation Management Scale for the administrators in schools" developed by Bülbül (2012a) was used. The "Personal Information Form" developed by the researcher was used to determine some demographic information belonging to school administrators to collect the data used in the research.

\section{Findings, Discussion and Conclusion}

When the findings obtained in the research were examined, it was concluded that the technology leadership competence perceptions of school administrators were generally high ( $\overline{\mathrm{X}}: 3.94)$ and innovation management competence perceptions were $(\overline{\mathrm{X}}: 4.23)$ very high.

When the literature was examined, there were studies similar to the results of this study. Supporting the results of this study, Bülbül and Çuhadar (2012), who used the same scale tool, revealed that school administrators generally perceive themselves as sufficient according to the technology leadership scale. Similarly, Banoğlu (2011) concluded that according to the results of the study, the administrators participating in the study had technology leadership competencies. Supporting the result of this study, Bülbül (2012b), who used the same measurement tool of, Innovation Management Competencies of School Administrators reached the conclusion that school administrators fully agree with their perceptions of competence in innovation management.

According to Technological Leadership Competencies and Innovation Management Competencies scale, school principals' mean scores were significantly higher than deputy principals. The average scores of the school administrators, participated in-service training related to information technologies. were significantly higher than the school administrators that didn't participate in-service training related to information technologies.

According to the main findings of the research, it was concluded that Technological Leadership Competencies and Innovation Management Competencies of the school administrators vary with position title and participation in-service training related to information technologies. In this study it was also concluded that, Technological Leadership Competencies and Innovation Management Competencies. of the school administrators were not vary with, gender, educational degree, subject and the school type.

When the findings of the study were examined, it was concluded that there was a positive and high correlation between School Administrators' Perceptions of Technological Leadership Competencies and Innovation Management Competencies. When the literature was examined, there were some studies that support this finding Esen, 2016; Demiraçan, 2019. 
The correct perception by the stakeholders in the educational organizations is quite important in order to achieve the goals of the "Turkey's Education Vision 2023 Document" that was prepared by the Ministry of National Education. It was recommended that some of the inservice training activities for school administrators should be converted from the practice of a participation certification to that of an accredited certification program to be run by universities. In the context, it's considered to be beneficial to cooperate between Ministry of National Education and Universities within the scope of in-service trainings. It was also recommended that Cooperation initiatives should be developed with universities and NGOs for face-to-face, formal, and/or distance training programs to support the vocational development of teachers and school administrators.

Keywords: Education management, administrator, leader, technology, inovasion, Turkey’s education vision 2023.

Öz: Bu çalışma, 2023 Eğitim Vizyonu'nda yer alan okul yöneticilerinin mesleki becerilerinin geliştirilmesi hedefinden hareketle okul yöneticilerinin teknoloji liderliği yeterlik algıları ile yenilik yönetimi yeterlikleri arasındaki ilişkinin incelenmesi amacıyla yapılan nicel bir çalışmadır. Bu araştırmada, genel tarama modellerinden ilişkisel tarama modeli kullanılmıştır. Bu araştırmanın evrenini, 2019-2020 eğitim öğretim yılı İstanbul ili Avcılar ilçesinde devlet okullarında görev yapan 172 yönetici oluşturmaktadır. Araştırmada örneklem alınmayarak evrende yer alan tüm okul yöneticilerine ulaşılmaya çalışılmış olup, bu çalışma 132 yöneticiyle gerçekleştirilmiştir. Verilerin toplanması için Hacıfazlıŏlu, Karadeniz ve Dalgıç'ın (2011a) geliştirmiş olduğu Teknoloji Liderliği Yeterlik Ölçeği ve Bülbül (2012a) tarafından geliştirilmiş olan Okullarda Yenilik Yönetimi Ölçeğinin yönetici formu kullanılmıştır. Teknoloji Liderliği Yeterlik Algıları Ölçeği ve Okul Yöneticilerinin Eğitim Örgütlerinde Yenilik Yönetimi Ölçeği puanlarının; cinsiyet, öğrenim durumu, branş, görev ünvanı ve bilişim teknolojileri alanında hizmet içi eğitim alma durumu değişkenine göre farklılaşıp farklılaşmadığını belirlemek üzere Mann Whitney-U Testi, görev yapılan okul türü değişkenine göre farklılaşıp farklılaşmadığını belirlemek üzere Kruskal Wallis-H Testi uygulanmıştır. Araştırmanın sonuçlarına göre, okul yöneticilerinin teknoloji liderliği yeterlik algılarının yeterli; yenilik yönetimi yeterlik algılarının ise çok yeterli olduğu tespit edilmiştir. Cinsiyet, öğrenim durumu, branş ve görev yapılan okul türüne göre anlamlı bir fark bulunmamış iken; görev unvanı ve bilişim teknolojileri alanında hizmet içi eğitim alma değişkenine göre anlamlı farklılık bulunmuştur. Okul müdürlerinin puan ortalamaları, müdür yardımcılarından ve bilişim teknolojileri alanında hizmet içi eğitim alan okul yöneticilerinin puan ortalamaları, hizmet içi eğitim almayanlara göre daha yüksektir. Okul yöneticilerinin teknoloji liderliği yeterlik algıları ile yenilik yönetimi yeterlikleri arasında pozitif yönde ve yüksek düzeyde korelasyon tespit edilmiştir.

Anahtar Kelimeler: Eğitim yönetimi, yönetici, lider, teknoloji, inovasyon, Türkiye eğitim vizyonu 2023.

\section{Giriş}

Bir organizasyonun başarısı için lider en önemli aktörlerin başında gelir. Alanyazın incelendiğinde liderlerin tarihsel sürece damga vuracak düzeyde olaylara imza attıkları görülmektedir (Güçlü, 2016:1).

İçinde bulunduğumuz 21. yüzyılda ekonomik, sosyal ve politik alanlarda meydana gelen değişiklik ve gelişmelerin etkisiyle yeni okul paradigması ortaya çıkmaktadır (Gümüşeli, 2001). Bilişim teknolojileri alanında ortaya çıkan gelişmeler 1şığında, yöneticinin kullandığ 1 yönetim araçları bile değişiklik göstermektedir. Sanal örgütler kapsamında, sanal sınıflar oluşturulabilmektedir. Ayrıca, sanal (online/virtual) sunumlar ve sanal toplantılar günlük yaşamın bir vazgeçilmezi haline gelmektedir (Koçel, 2018:439). Teknoloji artık toplumun her alanında kullanılmakla birlikte, eğitim kurumlarında da yönetim ve öğretme-öğrenme süreçleri bağlamında oldukça önemli unsurlardan biri haline gelmiştir.

Eğitimin niteliğinin arttırılması için eğitim kurumlarının nitelikli liderler tarafından yönetilmesi oldukça önemlidir (Şişman, 2012: III). Eğitim kurumlarının eğitim yönetimi alanında uzman (Bursalığlu, 2012: 6) ve lider özellikli yöneticiler tarafından yönetilmesi günümüzde önem kazanmaktadır. (Koçel, 2018: 591). 
Günümüzde, okul yöneticilerinin yeterliklerini yeniden tanımlamak oldukça önemlidir (Gümüşeli, 2001). Ayrıca, etkili okullar için yönetici yetiştirilmesinde çeşitli değişiklikler ve düzenlemeler yapılması gerekli görülmektedir (Çobanoğlu \& Badavan, 2017).

Milli Eğitim Bakanlığının 2018 yılında kamuoyu ile paylaşmış olduğu 2023 Eğitim Vizyonu Belgesi kapsamında, eğitimin niteliğinin arttırılması için bir yol haritası hazırlanmıştır. Bu bağlamda okul yöneticilerinin mesleki gelişimleri için bazı değişiklikler öngörülmektedir (MEB, 2018a). 2023 Eğitim Vizyonu Belgesi'nde belirtilen amaçlara ulaşılabilmesi hususunda, Milli Eğitim kurumlarında yer alan aktörlerin başında gelen okul yöneticilerine önemli görevler düşmektedir.

\section{Teknoloji Liderliği}

Dünya'da, son yıllarda teknoloji liderliği konusunda yapılan çalışmalar oldukça artmaktadır. $\mathrm{Bu}$ araştırmalar, çoğunlukla Uluslararası Eğitimde Teknoloji Topluluğu (ISTE) standartları kapsamında yapılmıştır (ISTE, 2002, 2009). ISTE tarafından, daha sonra Yöneticiler için Ulusal Eğitim Teknolojileri Standartları (NETS-A) kabul edilmiştir. NETS-A Standartları, yükseköğretim hariç tüm eğitim kademelerinde okul yöneticilerinin etkili bir teknoloji lideri olabilmeleri için sahip olmaları gereken bilgi ve becerileri tanımlamaktadır (ISTE, 2009).

ISTE standartlarından hareketle Anderson ve Dexter (2005), bir model tasarlamıştır. Ayrıca, teknoloji liderliği yeterlikleri üzerine de çalışmalar gerçekleştirilmiştir (Yu ve Durrington 2006; Afshari vd., 2009).

Eğitim kurumu yöneticilerinin teknoloji liderliği rollerini tespit etmek amacıyla 2009 yılında ISTE tarafından geliştirilen okul yöneticilerinin teknoloji liderliği yeterliklerinin (NETS-A) Türkiye'ye uygunluğunu belirlemeye yönelik bir araştırma yapmışlardır (Hacıfazlığ̆lu vd., 2010). ISTE tarafından 2009 yılı içinde NETS-A standartları tekrar değerlendirilmiş olup güncel hale getirilmiştir. Bu bağlamda teknoloji liderinde aranan özellikler şu şekilde belirtilmiştir: Vizyoner Liderlik, Dijital Çağ Öğrenme Kültürü, Profesyonel Uygulamada Mükemmellik: Sistematik Gelişim ve Dijital Vatandaşlık (Hacıfazlıoğlu vd., 2011a).

Milli Eğitim Bakanlığı (MEB) eğitim kurumlarında teknoloji kullanımını yaygınlaştırmak amacıyla çeşitli projeler yürütmüştür. Milli Eğitim Bakanlığının en kapsamlı projelerinden biri de 2010 y1lı içinde kamuoyu ile paylaşılan FATİH (Fırsatları Artırma ve Teknolojiyi İyileştirme Hareketi) Projesi'dir. Bu proje ile eğitimde tüm çocukların firsat eşitliği yakalaması ve bilişim teknolojilerinden yararlanması amaciyla etkileşimli tahtalar, öğrenci ve öğretmenlerin hizmetine sunulmuştur. FATIH Projesi, eğitim teknolojileri kullanımı alanında, dünyada uygulanan en büyük ve kapsamlı eğitim hareketi olma özelliği taşımaktadır (MEB, 2020).

FATİH Projesi kapsamında, bütün okullara yüksek hızda ve güvenli internet bağlantısı sunulmaktadır. Öğrenciler, okul ortamı dışında da öğrenim sürecine devam edebilmekte ve öğrendiklerini pekiştirebilmektedir. Ders notlarına, ders içi projelere ve ödevlere internet olan her yerden öğrenciler erişilebilmektedir. Böylece öğrenciler üretmiş oldukları bilgileri öğretmenleri ve sınıf arkadaşları ile paylaşabilmektedir (MEB, 2020).

Dünyada ortaya çıkan değişiklikler ve yenilikler sonucunda, uzaktan eğitim oldukça önemli hale gelmiştir. MEB, 2023 Eğitim Vizyonu Belgesinde yer alan yenilikçi uygulamalara olanak sağlanması ilkesinden hareketle eğitim kurumlarında yer alan tüm aktörlere yönelik uzaktan eğitim araçları ve içerikleri geliştirmiştir. Eğitim Bilişim Ağı (EBA) sayesinde yardımcı kaynaklara ve dokümanlara ulaşılabilmektedir. Millî Eğitim Bakanlığı dijital eğitim platformu EBA, uzaktan eğitim sürecinde oldukça önemli bir rol üstlenmiştir (MEB 2018a, 2020).

Günümüzde, teknolojide yaşanan gelişmelerin uzaktan eğitim yoluyla bütünleştirilmesi oldukça önem kazanmıştır. MEB, eğitim kurumlarındaki yöneticilerin eğitim teknolojileri ve dijital becerilerini geliştirmelerini hedeflemektedir. Bu bağlamda MEB eğitim teknolojilerinin kullanımını 
teşvik etmektedir çünkü okul yöneticileri bilişim teknolojileri alanında ortaya çıkan yeniliklerin eğitimle bütünleştirilmesinde temel rolü oynayacak aktörlerin başında gelmektedir.

\section{Yenilik Yönetimi}

Okul yöneticiliğine yönelik tarihsel süreç incelendiğinde, 18. yüzyılın başındaki başöğretmenlik rolünün yerini 20 . yüzyılın sonlarına doğru öğretim liderliği ve değişim liderliği rolünün aldığı belirtilmektedir (Williams, 2004; Akt. Gümüşeli, 2014:7).

Günümüzde, eğitim kurumlarında yer alan aktör ve kavramların yeni yapı ve anlayış içerisinde düşünülmesi oldukça önemlidir (Özdemir ve Kılınç, 2013). Bu bağlamda, eğitim kurumlarının amacına ulaşması için okul yöneticilerine büyük sorumluluklar düşmektedir (Günbayı, 2016). Eğitim kurumlarının amacına ulaşması için yenilenen öğretim becerilerini göz önünde bulundurarak, öğrenen örgütler doğrultusunda sürekli yenilenmesi ve 21. yüzyıl becerilerine dayalı olarak eğitim-öğretim süreçlerini yönetmesi beklenmektedir.

Okul müdürlüğü rolünün tarihsel evrimine ilişkin yapılan açıklamalar göstermektedir ki okul çevrelerinde meydana gelen değişme ve gelişmeler sürdükçe okul müdürlerinden beklenen rollerdeki değişmeler de devam edecektir (Gümüşeli, 2014:17).

Yabancı alanyazında olduğu gibi "inovasyon" (yenilik) kelimesinin Türkçedeki tam olarak karşılığının ne olduğu tartışılmaktadır (Bülbül, 2017: 45). Alanyazın incelendiğinde, dünyada yöneticilerin yenilik (inovasyon) yönetimi yeterliklerine ilişkin yapılan araştırmaların çoğunlukla ilk olarak işletmeler üzerinde gerçekleştirildiği söylenebilir.

Başarılı bir yenilik yönetimi sürecinde, bazı faktörlerin önemi karşımıza çıkmaktadır. Bu noktada örgüt kültürünün yenilikçi olması, liderin yenilik kavramının önemini içselleştirmesi ve yenilikçilik paradigmasını çalışma ilkesi olarak benimseyen çalışanlar oldukça önemlidir (Bülbül, 2017). Eğitim kurumlarında Bülbül, (2012a) yenilik süreçlerinin değerlendirilmesinde önemli bir rolü olan okullarda yenilik yönetimi ölçeğini Türkçeye uyarlamıştır.

Günümüzde, Hacıfazlığlu'na (2016) göre okul yöneticilerinin sahip olması gereken yeterliklerin başında yenilik ve yaratıcılık becerileri gelmektedir. Eğitimin niteliğinin arttırılması için okul yöneticilerinin yenilik yönetimi yeterlikleri oldukça önemlidir. Bu bağlamda, 21. yüzyılın gerektirdiği nitelik ve yeterliklere sahip olan eğitim yöneticilerinin yetiştirilmesi gerektiği ifade edilmektedir (Şişman, 2012).

Hacıfazlığlu'na (2016) göre;

1. 21. yüzy1la uygun öğretim becerileri eğitim ve öğretim süreçlerimizde ne kadar kullanılmaktadır?

2. Yaratıcılık, yenilik, eleştirel düșünme, takım çalışması, problem çözme, iletișim, bilișim teknolojileri, sosyal medya becerileri ve liderlik gibi 21. yüzyıl becerilerini okullarımızda uygulamaya çalışan yöneticiler kimdir?

3. Yenilik yönetimi becerileri doğrultusunda, okullarında bu vizyona ulaşmak için çalışan yöneticiler gerekli nitelik ve yeterliklere sahip midir?

Eğitim kurumlarında, yenilik yönetimi liderliği modeline ilişkin olarak; okul müdürü, liderlik takımları, deneyim paylaşım toplulukları, yaratıcılık, disiplinler arası program ve gelişim dosyaları uygulamaları, veli işbirliği, değişim ve yenilikçi yaklaşımlara dayalı okul kültürü ortaya çıkan boyutlardır (Hacıfazlıoğlu, 2016).

Hacıfazlığlu ve Aksu'nun (2015) geleceğin okul liderleri konulu okul müdürleriyle yaptıkları görüşmelere ilişkin araştırmanın sonuçlarına göre okullarda deneyim paylaşım topluluklarının kurulmasının önemi vurgulanmıştır. Bu bağlamda öğrenci, öğretmen, okul çevresi ve 
iş dünyası arasında deneyim paylaşımı en önemli husus olarak karşımıza çıkmaktadır (Hacıfazlıŏglu, 2016).

Alanyazın incelendiğinde; dünyada ve Türkiye'de teknoloji liderliği yeterliklerini inceleyen birçok araştırmaya rastlanmaktadır (Can, 2003,2008; Hacıfazlıŏlu, Karadeniz \& Dalgıç, 2010,201 b; Akbaba-Altun ve Gürer, 2008; Sincar, 2009; Banoğlu; 2011, Sincar ve Aslan, 2011; Bülbül ve Çuhadar, 2012; Cormican and O'Sullivan (2004); Oke (2004), Anderson ve Dexter, 2005; ISTE, 2002, 2009; Yu ve Durrington, 2006; Smith, Busi, Ball and Meer (2008); Afshari vd., 2009 ve Vlok (2012).

Son yıllarda Türkiye'de okul yöneticilerinin yenilik yönetimi yeterliklerine ilişkin yapılan araştırmaların giderek artış gösterdiği görülmektedir: Top (2011); Bülbül (2012b); Göl ve Bülbül (2012); Boydak ve Karabatak (2013); Ömür (2014); Argon, İsmetoğlu ve İşeri (2015); Karataş, Gök ve Özçetin (2015); Esen (2016); Öztürk (2017); Görgel (2018); Aydoğar (2018) ve Karaca (2019). Ancak okul yöneticilerinin teknoloji liderliği ile yenilik yönetimi yeterlikleri arasındaki ilişkiyi belirlemeye çalışan bir araştırmaya rastlanmamıştır.

$\mathrm{Bu}$ çalışmanın amacı, İstanbul ili Avcılar ilçesinde devlet okullarında görev yapan okul yöneticilerinin algılarına göre okul yöneticilerinin teknoloji liderliği yeterlikleri ile yenilik yönetimi yeterlikleri arasındaki ilişkiyi tespit etmek ve bazı demografik değişkenlere göre anlamlı bir farklılık olup olmadığını belirlemektir.

$\mathrm{Bu}$ amaca ulaşmak için aşağıdaki sorulara cevap aranmıştır:

1. Okul yöneticilerinin algılarına göre teknoloji liderliği yeterlikleri ile yenilik yönetimi yeterlikleri ne düzeydedir?

2. Okul yöneticilerinin algılarına göre teknoloji liderliği yeterlikleri ile yenilik yönetimi yeterlikleri bazı demografik değişkenlere göre anlamlı farklılık göstermekte midir?

3. Okul yöneticilerinin algılarına göre teknoloji liderliği yeterlikleri ile yenilik yönetimi yeterlikleri arasında anlamlı bir ilişki var mıdır?

$\mathrm{Bu}$ araştırmanın, eğitim kurumu yöneticilerinin teknoloji liderliği yeterlikleri ve yenilik yönetimi yeterliklerinin bilimsel olarak araştırılması ve geliştirilmesi için bir öneri getirerek bu alandaki benzer çalışmalara örnek oluşturacağı düşünülmektedir. Okul yöneticilerinin teknoloji liderliği ve yenilik yönetimi yeterliklerinin, öz yeterlik algılarına göre kapsamlı bir şekilde ortaya konulup anlaşılmasını sağlayacağı ve araştırma sonucunda çıkan veriler doğrultusunda, Milli Eğitim Bakanlığının 2023 Eğitim Vizyonu Belgesi’nde yer alan okul yöneticilerinin yetiştirilmesine yönelik yapılması hedeflenen hizmetiçi eğitim çalışmalarına katkı sağlayacağı düşünülmektedir.

\section{Yöntem}

\section{Araştırmanın Modeli}

Okul yöneticilerinin algılarına göre teknoloji liderliği ile yenilik yönetimi yeterlikleri düzeyi arasındaki ilişkiyi inceleme amacıyla gerçekleştirilen bu çalışmada, ilişkisel tarama modeli kullanılmıştır. Bu araştırma, nicel bir araştırmadır. Bu bağlamda, iki veya daha fazla değişken arasında birlikte değişimin varlığını, yönünü ve derecesini belirlemeyi amaçlayan ilişkisel tarama modelinde tasarlanmıştır (Karasar, 2016: 114).

Araştırmanın bağımlı değişkenini okul yöneticilerinin algılarına göre teknoloji liderliği yeterlikleri ile yenilik yönetimi yeterlikleri alt boyutları; bağımsız değişkenlerini ise okul yöneticilerine ait bazı demografik değişkenler oluşturmaktadır. 


\section{Evren ve Örneklem}

Bu araştırmanın evrenini, 2019-2020 akademik yılında, İstanbul ili Avcılar ilçesinde ilkokul, ortaokul ve liselerde görev yapan devlet okulu yöneticileri oluşturmaktadır.

Evrenin Avcılar ilçesi olarak seçilmesinin sebebi, araştırmacıların burada görev yapıyor olmasıdır. Evrende görev yapan tüm okul yöneticilerinin sayısının, çalışmanın evrenine genellenebilmesi için yeterli olması ve bölgede tüm evrene ulaşımın kolaylığı sebebiyle; doyma (Tam sayım örneklem seçimi) tekniği kullanılmıştır. Doyma Tekniği, evrendeki her birimin örnekleme katıldığ 1 örneklem seçim tekniğidir. Doyma Tekniği, küçük ve coğrafi yönden belirli bir alanda yoğunlaşan evrenler için daha uygundur (Lin, 1976). Araştırma kapsamında 132 okul yöneticisine ulaşı1mıştır.

Araştırma kapsamında görüşlerine başvurulan okul yöneticilerine ait cinsiyet, öğrenim durumu, branş, görev yapılan okul türü, görev unvanı ve bilişim teknolojileri alanında hizmet içi eğitim alma durumu değişkenlerine göre demografik bilgileri Tablo 1'de verilmiştir.

Tablo 1: Katılımcıların Demografik Özelliklerine Ait Frekans ve Yüzde Değerleri

\begin{tabular}{llll}
\hline Değişken & Düzey & $\boldsymbol{f}$ & $\boldsymbol{\%}$ \\
\hline \multirow{3}{*}{ Okul Kademesi } & İlkokul & 44 & 33,3 \\
& Ortaokul & 48 & 36,4 \\
& Lise & 40 & 30,3 \\
\hline \multirow{2}{*}{ Göreviniz } & Müdür & 38 & 28,8 \\
\hline \multirow{2}{*}{ Branş } & Müdür Yardımcısı & 94 & 71,2 \\
\hline \multirow{2}{*}{ Cinsiyet } & Sinıf Öğretmeni & 35 & 26,5 \\
& Branş Öğretmeni & 97 & 73,5 \\
\hline \multirow{2}{*}{ Öğrenim durumu } & Erkek & 108 & 81,8 \\
& Kadın & 24 & 18,2 \\
\hline Bilişim teknolojileri ile ilgili hizmet içi eğitim alma & Ön lisans & 0 & 0 \\
durumu & Lisans & 90 & 68,2 \\
\hline & Yüksek Lisans & 42 & 31,8 \\
\hline
\end{tabular}

Tablo 1'e göre araştırmaya katılan okul yöneticilerinin \%33,3'ü ilkokul, \%36,4'ü ortaokul ve \% 30,3'ü lise eğitim kurumlarında görev yapmaktadır. Katılımcıların \% 28,8'i müdür, \%71,2'si müdür yardımcısı olarak görev yapmaktadır. Katılımcı okul yöneticilerinin \% 26,5'i sınıf öğretmeni, \%73,5'i branş öğretmenidir. Okul yöneticilerinin \% 81,8'i erkek, \% 18,2'si ise kadın yöneticilerden oluşmaktadır. Katılımcıların \% 68,2 lisans, \%31,8'i yüksek lisans mezunudur. Okul yöneticilerinin $\%$ 37,1'i bilişim teknolojileri ile ilgili hizmet içi eğitim almış olup, \% 62,9'u bilişim teknolojileri ile ilgili hizmet içi eğitim almamıştır.

\section{Veri Toplama Aracı}

Çalışmadaki verileri elde etmek için okul yöneticilerine ait bazı demografik bilgileri saptamak amacıyla araştırmacıların geliştirmiş olduğu Kişisel Bilgi Formu kullanılmıştır.

Bu çalışmada, verilerin toplanması için Hacıfazlıoğlu, Karadeniz ve Dalgıç'ın (2011a) geliştirmiş olduğu Teknoloji Liderliği Yeterlik Ölçeği ve Bülbül (2012a) tarafından geliştirilmiş olan Okullarda Yenilik Yönetimi Ölçeği’nin yönetici formu kullanılmıştır. Bu ölçekte toplam 21 madde bulunmakta olup; " $1=$ Çok az" ve " $5=$ Çok yeterli" arasında yer alan beşli derecelendirme yer almaktadır.

$\mathrm{Bu}$ araştırma kapsamında ayrıca, veri toplama aracı olarak Bülbül (2012a) tarafindan geliştirilen Okullarda Yenilik Yönetimi Ölçeği'nin yönetici formu kullanılmıştır. Geçerlilik ve 
güvenilirlik çalışmaları araştırmacı tarafından (Bülbül, 2012a) tarafından düzenlenmiş olan ölçek 32 madde ve dört alt boyuttan oluşmaktadır.

Teknoloji Liderliği Yeterlik Algıları Ölçeğinin Alt Boyutlanına Ait Cronbach's Alpha $(\alpha)$ Katsayıları Toplam Ölçek için ,973; Vizyoner liderlik ,945, Dijital Çağ Öğrenme Kültürü ,953 Profesyonel Uygulamada Mükemmellik ,961 Sistematik Gelişim ,957 ve Dijital Vatandaşlık ,963 olarak tespit edilmiştir. Eğitim Örgütleri İçin Yenilik Yönetimi Ölçeğinin Alt Boyutlarına Ait Cronbach's Alpha $(\alpha)$ Katsayıları Toplam Ölçek için ,978; Girdi Yönetimi ,932 Yenilik Stratejisi ,936 Örgütsel Kültür ve Yap1 ,970 Proje Yönetimi ,978 olarak tespit edilmiştir. Bu araştırmada yapılan güvenirlik analizi sonucunda, ölçeklerin tüm alt boyutlarını ölçen ifadelere verilen cevapların güvenilir olduğu görülmektedir (Gliem ve Gliem, 2003: 76).

\section{Verilerin Toplanması ve Yorumlanması}

Araştırma kapsamında uygulanan ölçekleri Türkçeye uyarlayan ve geliştiren araştırmacılarla iletişime geçilerek araştırmada ölçeklerin kullanım izni alınmıştır. Anketlerin uygulanabilirliğine dair İstanbul İl Milli Eğitim Müdürlüğünden Valilik Oluru ile gerekli izinler alınmıştır.

Ölçeklerden elde edilen verilerin analiz edilmesi için SPSS 22 istatistik paket programı kullanılmıştır. Teknoloji Liderliği Yeterlik Algıları Ölçeği puanlarının, normal dağılıp dağılmadığını belirlemek amacıyla Kolmogorov-Smirnov testi kullanılmış $(n>50)$ ve $p<, 05$ olduğundan verilerin normal dağılım göstermediği tespit edilmiştir (İstatistik $=, 099 ; \mathrm{sd}=132 ; \mathrm{p}=, 003$ ). Okul Yöneticilerinin Eğitim Örgütlerinde Yenilik Yönetimi Ölçeği puanlarının, normal dağılıp dağılmadığını belirlemek amacıyla Kolmogorov-Smirnov testi kullanılmış $(n>50)$ ve $p<, 05$ olduğundan verilerin normal dağılım göstermediği tespit edilmiştir (İstatistik= $105 ; \mathrm{sd}=132$; $\mathrm{p}=, 001)$.

Teknoloji Liderliği Yeterlik Algıları Ölçeği ve Okul Yöneticilerinin Eğitim Örgütlerinde Yenilik Yönetimi Ölçeği puanlarının; cinsiyet, öğrenim durumu, branş, görev ünvanı ve bilişim teknolojileri alanında hizmet içi eğitim alma durumu değişkenine göre farklılaşıp farklılaşmadığını belirlemek üzere Mann Whitney-U Testi, görev yapılan okul türü değişkenine göre farklılaşıp farklılaşmadığını belirlemek üzere Kruskal Wallis-H Testi uygulanarak, manidarlık .05 düzeyinde sınanmıştır.

\section{Bulgular}

$\mathrm{Bu}$ bölümde araştırma sorularına sırası ile cevap aranmaktadır. Okul Yöneticilerinin Teknoloji Liderliği Yeterlik Ölçeğine ilişkin Algıları Tablo 1'de gösterilmiştir.

Tablo 2: Okul Yöneticilerinin Teknoloji Liderliği Yeterlik Ölçeğine İlişkin Betimsel İstatistikler

\begin{tabular}{|c|c|c|}
\hline Teknoloji Liderliği Yeterlik Algıları Alt Boyutları & $\overline{\mathbf{X}}$ & SS \\
\hline Vizyoner liderlik & 3,9975 & ,854 \\
\hline Dijital Çağ Öğrenme Kültürü & 3,9545 & 849 \\
\hline Profesyonel Uygulamada Mükemmellik & 4,0777 & ,828 \\
\hline Sistematik Gelişim & 3,8742 & ,840 \\
\hline Dijital Vatandaşlik & $\begin{array}{l}3,8258 \\
3,9405\end{array}$ & $\begin{array}{l}, 931 \\
, 743\end{array}$ \\
\hline
\end{tabular}

Tablo 2'ye göre araştırmaya katılan okul yöneticilerinin Teknoloji Liderliği Yeterlik Algılarına İlişkin puanların toplam ölçek düzeyinde yeterli ( $\overline{\mathrm{X}}: 3.94)$ olduğu görülmektedir.

Tablo 3: Okul Yöneticilerinin Eğitim Örgütlerinde Yenilik Yönetimi Yeterliklerine İlişkin Betimsel İstatistikler

\begin{tabular}{lcc}
\hline Eğitim Örgütlerinde Yenilik Yönetimi Alt Boyutları & $\overline{\mathbf{X}}$ & SS \\
\hline Girdi Yönetimi & 3,8879 &, 894 \\
\hline Yenilik Stratejisi & 4,0821 &, 767 \\
\hline Örgütsel Kültür ve Yap1 & 4,3232 &, 766 \\
\hline
\end{tabular}




\begin{tabular}{lrrr}
\hline \hline Proje Yönetimi & Toplam & 4,3601 &, 656 \\
\hline & T,2273 &, 644 \\
\hline
\end{tabular}

Tablo 3'e göre araştırmaya katılan okul yöneticilerinin Eğitim Örgütlerinde Yenilik Yönetimi Algılarına İlişkin puanların toplam ölçek düzeyinde çok yeterli ( $\overline{\mathrm{X}}: 4.23)$ olduğu görülmektedir.

Tablo 4: Okul Yöneticilerinin Teknoloji Liderliği Yeterlik Algıları Ölçeği Puanlarının Görev Unvanı Değişkenine Göre Mann Whitney U Testi Sonuçları

\begin{tabular}{|c|c|c|c|c|c|c|c|}
\hline Puanlar & Gruplar & $\mathbf{n}$ & $\overline{\mathbf{X}}_{\text {sira }}$ & $\sum_{\text {sira }}$ & $\mathbf{U}$ & $\mathbf{z}$ & $\mathbf{p}$ \\
\hline \multirow[b]{2}{*}{ Vizyoner Liderlik } & Müdür & 38 & 82,91 & 3150,50 & \multirow[b]{2}{*}{1162,50} & \multirow[b]{2}{*}{$-3,248$} & \multirow[b]{2}{*}{,001 } \\
\hline & $\begin{array}{c}\text { Müdür Yardımcısı } \\
\text { Toplam }\end{array}$ & $\begin{array}{c}94 \\
132\end{array}$ & 59,87 & 5627,50 & & & \\
\hline \multirow[b]{2}{*}{$\begin{array}{l}\text { Dijital Çağ Öğrenme } \\
\text { Kültürü }\end{array}$} & Müdür & 38 & 82,83 & 3147,50 & \multirow[b]{2}{*}{1165,50} & \multirow[b]{2}{*}{$-3,162$} & \multirow[b]{2}{*}{, 002} \\
\hline & $\begin{array}{c}\text { Müdür Yardımcisı } \\
\text { Toplam }\end{array}$ & $\begin{array}{c}90 \\
94 \\
132\end{array}$ & 59,90 & 5630,50 & & & \\
\hline \multirow[b]{2}{*}{$\begin{array}{l}\text { Profesyonel Uygulamada } \\
\text { Mükemmellik }\end{array}$} & Müdür & 38 & 79,97 & 3039,00 & \multirow[b]{2}{*}{1274,00} & \multirow[b]{2}{*}{$-2,660$} & \multirow[b]{2}{*}{, 008} \\
\hline & $\begin{array}{c}\text { Müdür Yardımcisı } \\
\text { Toplam }\end{array}$ & $\begin{array}{c}94 \\
132\end{array}$ & 61,05 & 5739,00 & & & \\
\hline \multirow[b]{2}{*}{ Sistematik Gelişim } & Müdür & 38 & 79,47 & 3020,00 & \multirow[b]{2}{*}{1293,00} & \multirow[b]{2}{*}{$-2,518$} & \multirow[b]{2}{*}{, 012} \\
\hline & $\begin{array}{c}\text { Müdür Yardımcisı } \\
\text { Toplam }\end{array}$ & $\begin{array}{c}94 \\
132\end{array}$ & 61,26 & 5758,00 & & & \\
\hline \multirow[b]{2}{*}{ Dijital Vatandaşlık } & Müdür & 38 & 70,07 & 2662,50 & \multirow[b]{2}{*}{1650,50} & \multirow[b]{2}{*}{,- 696} & \multirow[b]{2}{*}{,486 } \\
\hline & $\begin{array}{c}\text { Müdür Yardımcisı } \\
\text { Toplam }\end{array}$ & $\begin{array}{c}94 \\
132\end{array}$ & 65,06 & 6115,50 & & & \\
\hline \multirow[b]{2}{*}{ Toplam } & Müdür & 38 & 79,07 & 3004,50 & \multirow[b]{2}{*}{1308,50} & \multirow[b]{2}{*}{$-2,404$} & \multirow[b]{2}{*}{,016 } \\
\hline & $\begin{array}{l}\text { Müdür Yardımcısı } \\
\text { Toplam }\end{array}$ & $\begin{array}{c}94 \\
132\end{array}$ & 61,42 & 5773,50 & & & \\
\hline
\end{tabular}

Tablo 4'te görüldüğü üzere, Teknoloji Liderliği Yeterlik Algıları ölçeği puanlarının görev unvanı değişkenine göre yapılan Mann Whitney $U$ analizi sonucunda, toplam ölçek puanı $\quad(U=$ 1308,50; $\mathrm{p}<0,05)$ ve Vizyoner Liderlik (U = 1162,50; $\mathrm{p}<0,05)$, Dijital Çağ Öğrenme Kültürü ( $U$ = 1165,50; $\mathrm{p}<0,05)$, Profesyonel Uygulamada Mükemmellik ( $\mathrm{U}=1274,00 ; \mathrm{p}<0,05)$, Sistematik Gelişim $(U=1293,00 ; p<0,05)$ için anlamlı farklılık bulunmuştur. Sadece dijital Vatandaşlık alt boyutunda $(\mathrm{U}=1650,50 ; \mathrm{p}>0,05)$ anlamlı fark bulunmamıştır. Teknoloji Liderliği Yeterlik Algıları Ölçeği'ne ilişkin bulgular incelendiğinde okul müdürlerinin, müdür yardımcılarına göre daha yüksek aritmetik ortalamaya sahip oldukları görülmektedir. 
Tablo 5: Okul Yöneticilerinin Teknoloji Liderliği Yeterlik Algıları Ölçeği Puanlarının Biliş̧im Teknolojileri Alanında Hizmet İçi Eğitim Alma Durumu Değişkenine Göre Mann Whitney U Testi

\begin{tabular}{|c|c|c|c|c|c|c|c|}
\hline \multicolumn{8}{|c|}{ Sonuçları } \\
\hline Puanlar & Gruplar & $\mathbf{N}$ & $\overline{\mathbf{X}}_{\text {sira }}$ & $\sum$ sira & $\mathbf{U}$ & $\mathbf{z}$ & p \\
\hline \multirow{3}{*}{$\begin{array}{l}\text { Vizyoner } \\
\text { Liderlik }\end{array}$} & Evet & 49 & 76,79 & 3762,50 & \multirow{3}{*}{1529,50} & \multirow{3}{*}{$-2,460$} & \multirow{3}{*}{,014 } \\
\hline & Hayır & 83 & & & & & \\
\hline & Toplam & 132 & 60,43 & 5015,50 & & & \\
\hline \multirow{3}{*}{$\begin{array}{c}\text { Dijital Çă̆ } \\
\text { Öğrenme Kültürü }\end{array}$} & Evet & 49 & 78,62 & 3852,50 & \multirow{3}{*}{1439,50} & \multirow{3}{*}{$-2,837$} & \multirow{3}{*}{,005 } \\
\hline & Hayır & 83 & 5934 & 492550 & & & \\
\hline & Toplam & 132 & & 4925,00 & & & \\
\hline \multirow{3}{*}{$\begin{array}{c}\text { Profesyonel } \\
\text { Uygulamada } \\
\text { Mükemmellik }\end{array}$} & Evet & 49 & 76,89 & 3767,50 & \multirow{3}{*}{1524,50} & \multirow{3}{*}{$-2,478$} & \multirow{3}{*}{,013 } \\
\hline & Hayır & 83 & 6037 & 501050 & & & \\
\hline & Toplam & 132 & 60,37 & 5010,50 & & & \\
\hline \multirow{3}{*}{$\begin{array}{l}\text { Sistematik } \\
\text { Gelişim }\end{array}$} & Evet & 49 & 73,51 & 3602,00 & \multirow{3}{*}{1690,00} & \multirow{3}{*}{$-1,644$} & \multirow{3}{*}{, 100} \\
\hline & Hayır & 83 & 6236 & 517600 & & & \\
\hline & Toplam & 132 & & $31 / 0,00$ & & & \\
\hline \multirow{3}{*}{$\begin{array}{c}\text { Dijital } \\
\text { Vatandaşlık }\end{array}$} & Evet & 49 & 73,43 & 3598,00 & \multirow{3}{*}{1694,00} & \multirow{3}{*}{$-1,635$} & \multirow{3}{*}{,102 } \\
\hline & Hayır & 83 & 6241 & 518000 & & & \\
\hline & Toplam & 132 & 62,41 & 5180,00 & & & \\
\hline \multirow{3}{*}{ Toplam } & Evet & 49 & 78,00 & 3822,00 & \multirow{3}{*}{1470,00} & \multirow{3}{*}{$-2,659$} & \multirow{3}{*}{,008 } \\
\hline & Hayır & 83 & 59.71 & 495600 & & & \\
\hline & Toplam & 132 & & & & & \\
\hline
\end{tabular}

Tablo 5'te görüldüğü üzere, Teknoloji Liderliği Yeterlik Algıları ölçeği puanlarının bilişim teknolojileri alanında hizmet içi eğitim alma durumu değişkenine göre yapılan Mann Whitney $\mathrm{U}$ analizi sonucunda, toplam ölçek puanı $U=1470,00 ; p<0,05$, Vizyoner Liderlik $(U=1529,50 ; p<$ $0,05)$, Dijital Çağ Ögrenme Kültürü $(U=1439,50 ; p<0,05)$ ve Profesyonel Uygulamada Mükemmellik $(U=1524,50 ; p<0,05)$ için anlamlı farkl1lık bulunmuştur. Sistematik Gelişim $(U=$ $1690,00 ; p>0,05)$ ve Dijital Vatandaşlık $(U=1694,00 ; p>0,05)$ anlamlı bulunmamıştır. Teknoloji Liderliği Yeterlik Algıları ölçeğine ilişkin bulgular incelendiğinde, hizmet içi eğitim alanlar, hizmet içi eğitim almayanlara göre daha yüksek aritmetik ortalamaya sahip oldukları görülmektedir.

Tablo 6: Okul Yöneticilerinin Teknoloji Liderliği Yeterlik Algıları Ölçeği Puanlarının Cinsiyet Değişkenine Göre Mann Whitney U Testi Sonuçları

\begin{tabular}{|c|c|c|c|c|c|c|c|}
\hline Puanlar & Gruplar & $\mathbf{N}$ & $\overline{\mathbf{X}}_{\text {sira }}$ & $\sum_{\text {sira }}$ & $\mathbf{U}$ & $\mathbf{z}$ & $\mathbf{p}$ \\
\hline \multirow{3}{*}{ Vizyoner Liderlik } & Erkek & 108 & 68,44 & 7392,00 & & & \\
\hline & Kadın & 24 & 57,75 & 1386,00 & 1086,00 & $-1,284$ &, 199 \\
\hline & Toplam & 132 & & & & & \\
\hline \multirow{3}{*}{ Dijital Çağ Öğrenme Kültürü } & Erkek & 108 & 69,08 & 7461,00 & & & \\
\hline & Kadın & 24 & 54,88 & 1317,00 & 1017,00 & $-1,669$ & ,095 \\
\hline & Toplam & 132 & & & & & \\
\hline \multirow{3}{*}{ Profesyonel Uygulamada Mükemmellik } & Erkek & 108 & 67,57 & 7298,00 & & & \\
\hline & Kadın & 24 & 61,67 & 1480,00 & 1180,00 &,- 707 & ,479 \\
\hline & Toplam & 132 & & & & & \\
\hline \multirow{3}{*}{ Sistematik Gelişim } & Erkek & 108 & 68,44 & 7391,50 & & & \\
\hline & Kadın & 24 & 57,77 & 1386,50 & 1086,50 & $-1,256$ & ,209 \\
\hline & Toplam & 132 & & & & & \\
\hline \multirow{3}{*}{ Dijital Vatandaşlık } & Erkek & 108 & 67,20 & 7258,00 & & & \\
\hline & Kadın & 24 & 63,33 & 1520,00 & 1220,00 &,- 459 & ,647 \\
\hline & Toplam & 132 & & & & & \\
\hline \multirow{3}{*}{ Toplam } & Erkek & 108 & 68,17 & 7362,50 & & & \\
\hline & Kadın & 24 & 58,98 & 1415,50 & 1115,50 & $-1,067$ & ,286 \\
\hline & Toplam & 132 & & & & & \\
\hline
\end{tabular}

Tablo 6'ya göre, eğitim kurumu yöneticilerinin teknoloji liderliği yeterliği ölçeği puanlarının cinsiyet değişkeni bağlamında anlamlı bir farklılık olmadığı tespit edilmiştir. 
Tablo 7: Okul Yöneticilerinin Teknoloji Liderliği Yeterlik Algıları Ölçeği Puanlarının Öğrenim Durumu Değişkenine Göre Mann Whitney U Testi Sonuçları

\begin{tabular}{|c|c|c|c|c|c|c|c|}
\hline Puanlar & Gruplar & $\mathbf{N}$ & $\overline{\mathbf{X}}_{\text {sira }}$ & $\sum$ sira & $\mathbf{U}$ & $\mathbf{z}$ & $\mathbf{p}$ \\
\hline \multirow{3}{*}{ Vizyoner Liderlik } & Lisans & 90 & 64,91 & 5842,00 & & & \\
\hline & Lisansüstü & 42 & 69,90 & 2936,00 & 1747,00 &,- 724 & ,469 \\
\hline & Toplam & 132 & & & & & \\
\hline \multirow{3}{*}{ Dijital Çağ Öğrenme Kültürü } & Lisans & 90 & 63,58 & 5722,00 & & & \\
\hline & Lisansüstü & 42 & 72,76 & 3056,00 & 1627,00 & $-1,303$ & ,193 \\
\hline & Toplam & 132 & & & & & \\
\hline \multirow{3}{*}{ Profesyonel Uygulamada Mükemmellik } & Lisans & 90 & 63,09 & 5678,00 & & & \\
\hline & Lisansüstü & 42 & 73,81 & 3100,00 & 1583,00 & $-1,551$ & ,121 \\
\hline & Toplam & 132 & & & & & \\
\hline \multirow{3}{*}{ Sistematik Gelişim } & Lisans & 90 & 63,73 & 5736,00 & & & \\
\hline & Lisansüstü & 42 & 72,43 & 3042,00 & 1641,00 & $-1,236$ & ,216 \\
\hline & Toplam & 132 & & & & & \\
\hline \multirow{3}{*}{ Dijital Vatandaşlık } & Lisans & 90 & 66,95 & 6025,50 & & & \\
\hline & Lisansüstü & 42 & 65,54 & 2752,50 & 1849,50 &,- 202 & ,840 \\
\hline & Toplam & 132 & & & & & \\
\hline \multirow{3}{*}{ Toplam } & Lisans & 90 & 65,74 & 5916,50 & & & \\
\hline & Lisansüstü & 42 & 68,13 & 2861,50 & 1821,50 &,- 335 & ,737 \\
\hline & Toplam & 132 & & & & & \\
\hline
\end{tabular}

Tablo 7'ye göre, eğitim kurumu yöneticilerinin teknoloji liderliği yeterliği ölçeği puanlarının öğrenim durumu değişkeni bağlamında anlamlı bir farklılık olmadığı bulunmuştur.

Tablo 8: Okul Yöneticilerinin Teknoloji Liderliği Yeterlik Algıları Ölçeği Puanlarının Branş Değişkenine Göre Mann Whitney U Testi Sonuçları

\begin{tabular}{|c|c|c|c|c|c|c|c|}
\hline Puanlar & Gruplar & $\mathbf{N}$ & $\overline{\mathbf{X}}_{\text {sira }}$ & $\sum$ ssra & $\mathbf{U}$ & $\mathbf{z}$ & $\mathbf{p}$ \\
\hline \multirow{3}{*}{ Vizyoner Liderlik } & Sinıf Öğretmeni & 35 & 60,23 & 2108,00 & & & \\
\hline & Branş Öğretmeni & 97 & 68,76 & 6670,00 & 1478,00 & $1 \overline{173}$ &, 241 \\
\hline & Toplam & 132 & & & & & \\
\hline \multirow{3}{*}{ Dijital Çağ Öğrenme Kültürü } & Sınıf Öğretmeni & 35 & 62,39 & 2183,50 & & & \\
\hline & Branş Öğretmeni & 97 & 67,98 & 6594,50 & 1553,50 &,- 753 & ,452 \\
\hline & Toplam & 132 & & & & & \\
\hline \multirow{3}{*}{$\begin{array}{l}\text { Profesyonel Uygulamada } \\
\text { Mükemmellik }\end{array}$} & Sınıf Öğretmeni & 35 & 65,77 & 2302,00 & & & \\
\hline & Branş Öğretmeni & 97 & 66,76 & 6476,00 & 1672,00 &,- 136 & ,892 \\
\hline & Toplam & 132 & & & & & \\
\hline \multirow{3}{*}{ Sistematik Gelişim } & Sınıf Öğretmeni & 35 & 62,77 & 2197,00 & & & \\
\hline & Branş Öğretmeni & 97 & 67,85 & 6581,00 & 1567,00 &,- 684 & ,494 \\
\hline & Toplam & 132 & & & & & \\
\hline \multirow{3}{*}{ Dijital Vatandaşlık } & Sınıf Öğretmeni & 35 & 67,20 & 2352,00 & & & \\
\hline & Branş Öğretmeni & 97 & 66,25 & 6426,00 & 1673,00 &,- 129 & ,897 \\
\hline & Toplam & 132 & & & & & \\
\hline \multirow{3}{*}{ Toplam } & Sınıf Öğretmeni & 35 & 61,94 & 2168,00 & & & \\
\hline & Branş Öğretmeni & 97 & 68,14 & 6610,00 & 1538,00 &,- 824 & ,410 \\
\hline & Toplam & 132 & & & & & \\
\hline
\end{tabular}

Tablo 8'e göre, eğitim kurumu yöneticilerinin teknoloji liderliği yeterliği ölçeği puanlarının branş değişkeni bağlamında anlamlı bir farklılık olmadığı tespit edilmiştir. 
Tablo 9: Okul Yöneticilerinin Teknoloji Liderliği Yeterlik Algıları Ölçeği Puanlarının Görev Yapılan Okul Türü Değişkenine Göre Kruskal Wallis Testi Sonuçları

\begin{tabular}{|c|c|c|c|c|c|c|}
\hline Puanlar & Gruplar & $\mathbf{N}$ & $\overline{\mathbf{X}}_{\text {sIra }}$ & sd & $\mathbf{X}^{2}$ & $\mathbf{p}$ \\
\hline \multirow{4}{*}{ Vizyoner Liderlik } & İlkokul & 44 & 59,86 & \multirow{4}{*}{2} & \multirow{4}{*}{2,332} & \multirow{4}{*}{,312 } \\
\hline & Ortaokul & 48 & 71,42 & & & \\
\hline & Lise & 40 & 67,90 & & & \\
\hline & Toplam & 132 & & & & \\
\hline \multirow{4}{*}{ Dijital Çağ Öğrenme Kültürü } & İlkokul & 44 & 63,84 & \multirow{4}{*}{2} & \multirow{4}{*}{, 441} & \multirow{4}{*}{,802 } \\
\hline & Ortaokul & 48 & 69,06 & & & \\
\hline & Lise & 40 & 66,35 & & & \\
\hline & Toplam & 132 & & & & \\
\hline \multirow{4}{*}{ Profesyonel Uygulamada Mükemmellik } & İlkokul & 44 & 65,89 & \multirow{4}{*}{2} & \multirow{4}{*}{, 560} & \multirow{4}{*}{,756 } \\
\hline & Ortaokul & 48 & 69,46 & & & \\
\hline & Lise & 40 & 63,63 & & & \\
\hline & Toplam & 132 & 63,84 & & & \\
\hline \multirow{4}{*}{ Sistematik Gelişim } & İlkokul & 44 & 63,55 & \multirow{4}{*}{2} & \multirow{4}{*}{, 574} & \multirow{4}{*}{,751 } \\
\hline & Ortaokul & 48 & 66,48 & & & \\
\hline & Lise & 40 & 69,78 & & & \\
\hline & Toplam & 132 & & & & \\
\hline \multirow{4}{*}{ Dijital Vatandaşlık } & İlkokul & 44 & 68,17 & \multirow{4}{*}{2} & \multirow{4}{*}{, 183} & \multirow{4}{*}{,913 } \\
\hline & Ortaokul & 48 & 64,84 & & & \\
\hline & Lise & 40 & 66,65 & & & \\
\hline & Toplam & 132 & & & & \\
\hline \multirow{4}{*}{ Toplam } & İlkokul & 44 & 63,57 & \multirow{4}{*}{2} & \multirow{4}{*}{,873 } & \multirow{4}{*}{,646 } \\
\hline & Ortaokul & 48 & 70,55 & & & \\
\hline & Lise & 40 & 64,86 & & & \\
\hline & Toplam & 132 & 63,55 & & & \\
\hline
\end{tabular}

Tablo 9'a göre, eğitim kurumu yöneticilerinin teknoloji liderliği yeterliği ölçeği puanlarının okul türü değişkeni bağlamında anlamlı bir farklılık olmadığı tespit edilmiştir.

Tablo 10: Okul Yöneticilerinin Eğitim Örgütlerinde Yenilik Yönetimi Ölçeği Puanlarının Görev Ünvanı Değişkenine Göre Mann Whitney U Testi Sonuçları

\begin{tabular}{|c|c|c|c|c|c|c|c|}
\hline Puanlar & Gruplar & $\mathbf{N}$ & $\overline{\mathbf{X}}_{\text {sira }}$ & $\sum_{\text {sira }}$ & $\mathbf{U}$ & $\mathbf{z}$ & $\mathbf{p}$ \\
\hline \multirow{3}{*}{ Girdi Yönetimi } & Müdür & 38 & 78,16 & 2970,00 & \multirow{3}{*}{1343,00} & \multirow{3}{*}{$-2,240$} & \multirow{3}{*}{, 025} \\
\hline & Müdür Yardımcısı & 94 & 6170 & & & & \\
\hline & Toplam & 132 & 01,19 & 5808,00 & & & \\
\hline \multirow{3}{*}{ Yenilik Stratejisi } & Müdür & 38 & 79,13 & 3007,00 & \multirow{3}{*}{1306,00} & \multirow{3}{*}{$-2,437$} & \multirow{3}{*}{, 015} \\
\hline & Müdür Yardımcısı & 94 & 6139 & 577100 & & & \\
\hline & Toplam & 132 & 61,39 & $5 / 11,00$ & & & \\
\hline \multirow{3}{*}{$\begin{array}{c}\text { Örgütsel Külttür ve } \\
\text { Yap1 }\end{array}$} & Müdür & 38 & 78,72 & 2991,50 & \multirow{3}{*}{1321,50} & \multirow{3}{*}{$-2,400$} & \multirow{3}{*}{, 016} \\
\hline & Müdür Yardımcısı & 94 & 61.56 & 5786.50 & & & \\
\hline & Toplam & 132 & (1, & & & & \\
\hline \multirow{3}{*}{ Proje Yönetimi } & Müdür & 38 & 82,11 & 3120,00 & \multirow{3}{*}{1193,00} & \multirow{3}{*}{$-3,014$} & \multirow{3}{*}{, 003} \\
\hline & Müdür Yardımcısı & 94 & 6019 & 565800 & & & \\
\hline & Toplam & 132 & 00,19 & 5038,00 & & & \\
\hline \multirow{3}{*}{ Toplam } & Müdür & 38 & 82,11 & 3120,00 & \multirow{3}{*}{1193,00} & \multirow{3}{*}{$-2,982$} & \multirow{3}{*}{, 003} \\
\hline & Müdür Yardımcısı & 94 & 60,19 & 5658,00 & & & \\
\hline & Toplam & 132 & 00,13 & (300, & & & \\
\hline
\end{tabular}

Tablo 10'da görüldüğü üzere, Okul Yöneticilerinin Eğitim Örgütlerinde Yenilik Yönetimi ölçeği puanlarının görev ünvanı değişkenine göre yapılan Mann Whitney $U$ analizi sonucunda, toplam ölçek puanı $(U=1193,00 ; p<0,05)$ ve tüm alt boyutlarda Girdi Yönetimi $(U=1343,00 ; p<$ $0,05)$, Yenilik Stratejisi $(U=1306,00 ; p<0,05)$, Örgütsel Kültür ve Yap1 $(U=1321,50 ; p<0,05)$, Proje Yönetimi $(U=1193,00 ; p<0,05)$ için anlamlı farklılık bulunmuştur. 
Eğitim Örgütlerinde Yenilik Yönetimi Ölçeği'nin toplam ve alt boyutlara ilişkin bulgular incelendiğinde, okul müdürlerinin, müdür yardımcılarına göre daha yüksek aritmetik ortalamaya sahip oldukları görülmektedir.

Tablo 11: Okul Yöneticilerinin Eğitim Örgütlerinde Yenilik Yönetimi Ölçeği Puanlarının Bilişim Teknolojileri Alanında Hizmet İçi Eğitim Alma Durumu Değişkenine Göre Mann Whitney U Testi

\begin{tabular}{|c|c|c|c|c|c|c|c|}
\hline & & & & & & & \\
\hline Puanlar & Gruplar & $\mathbf{N}$ & $\overline{\mathbf{X}}_{\text {sira }}$ & $\sum_{\text {sira }}$ & $\mathbf{U}$ & $\mathbf{z}$ & p \\
\hline \multirow{3}{*}{ Girdi Yönetimi } & Evet & 49 & 75,83 & 3715,50 & \multirow{3}{*}{1576,50} & \multirow{3}{*}{$-2,166$} & \multirow{3}{*}{, 030} \\
\hline & Hayır & 83 & & & & & \\
\hline & Toplam & 132 & 60,99 & 5062,50 & & & \\
\hline \multirow{3}{*}{ Yenilik Stratejisi } & Evet & 49 & 75,78 & 3713,00 & \multirow{3}{*}{1579,00} & \multirow{3}{*}{$-2,163$} & \multirow{3}{*}{, 031} \\
\hline & Hayır & 83 & & & & & \\
\hline & Toplam & 132 & 61,02 & 5065,00 & & & \\
\hline \multirow{3}{*}{ Örgütsel Kültür ve Yap1 } & Evet & 49 & 74,41 & 3646,00 & \multirow{3}{*}{1646,00} & \multirow{3}{*}{$-1,876$} & \multirow{3}{*}{, 061} \\
\hline & Hayır & 83 & & & & & \\
\hline & Toplam & 132 & 61,83 & 5132,00 & & & \\
\hline \multirow[b]{2}{*}{ Proje Yönetimi } & Evet & 49 & 74,61 & 3656,00 & \multirow{3}{*}{1636,00} & \multirow[b]{2}{*}{$-1,894$} & \multirow[b]{2}{*}{, 058} \\
\hline & Hayır & 83 & 61,71 & 5122,00 & & & \\
\hline \multirow{3}{*}{ Toplam } & $\begin{array}{c}\text { Toplam } \\
\text { Evet }\end{array}$ & $\frac{132}{49}$ & 76,63 & 3755,00 & & \multirow{3}{*}{$-2,340$} & \multirow{3}{*}{,019 } \\
\hline & Hayır & 83 & & & \multirow[t]{2}{*}{1537,00} & & \\
\hline & Toplam & 132 & 60,52 & 5023,00 & & & \\
\hline
\end{tabular}

Tablo 11'de görüldüğü üzere, Okul Yöneticilerinin Eğitim Örgütlerinde Yenilik Yönetimi ölçeği puanlarının bilişim teknolojileri alanında hizmetiçi eğitim alma durumu değişkenine göre yapılan Mann Whitney $U$ analizi sonucunda, toplam ölçek puanı $(U=1537,00 ; p<0,05)$, Girdi Yönetimi ( $U=1576,50 ; p<0,05)$ ve Yenilik Stratejisi $(U=1579,00 ; p<0,05)$ için anlamlı farklılık bulunmuştur. Örgütsel Kültür ve Yapı $(U=1646,00 ; p>0,05)$ ve Proje Yönetimi $(U=1636,00 ; p>$ $0,05)$ için anlamlı bulunmamıştır. Eğitim Örgütlerinde Yenilik Yönetimi Ölçeği’ne ilişkin bulgular incelendiğinde, hizmet içi eğitim alan yöneticilerin, hizmet içi eğitim almayanlara göre daha yüksek aritmetik ortalamaya sahip oldukları görülmektedir.

Tablo 12: Okul Yöneticilerinin Eğitim Örgütlerinde Yenilik Yönetimi Ölçeği Puanlarının Cinsiyet Değişkenine Göre Mann Whitney U Testi Sonuçları

\begin{tabular}{|c|c|c|c|c|c|c|c|}
\hline Puanlar & Gruplar & $\mathbf{N}$ & $\overline{\mathbf{X}}_{\text {sira }}$ & $\sum$ sira & $\mathbf{U}$ & $\mathbf{z}$ & p \\
\hline \multirow{3}{*}{ Girdi Yönetimi } & Erkek & 108 & 68,29 & 7375,50 & & & \\
\hline & Kadın & 24 & 58,44 & 1402,50 & 1102,50 & $-1,149$ & ,251 \\
\hline & Toplam & 132 & & & & & \\
\hline \multirow{3}{*}{ Yenilik Stratejisi } & Erkek & 108 & 67,87 & 7329,50 & & & \\
\hline & Kadın & 24 & 60,35 & 1448,50 & 1148,50 &,- 879 &, 379 \\
\hline & Toplam & 132 & & & & & \\
\hline \multirow{3}{*}{ Örgütsel Kültür ve Yap1 } & Erkek & 108 & 66,82 & 7217,00 & & & \\
\hline & Kadın & 24 & 65,04 & 1561,00 & 1261,00 &,- 212 &, 832 \\
\hline & Toplam & 132 & & & & & \\
\hline \multirow{3}{*}{ Proje Yönetimi } & Erkek & 108 & 67,35 & 7273,50 & & & \\
\hline & Kadın & 24 & 62,69 & 1504,50 & 1204,50 &,- 546 &, 585 \\
\hline & Toplam & 132 & & & & & \\
\hline \multirow{3}{*}{ Toplam } & Erkek & 108 & 67,72 & 7314,00 & & & \\
\hline & Kadın & 24 & 61,00 & 1464,00 & 1164,00 &,- 779 & ,436 \\
\hline & Toplam & 132 & & & & & \\
\hline
\end{tabular}

Tablo 12'ye göre, okul yöneticilerinin eğitim örgütlerinde yenilik yönetimi ölçeği puanlarının cinsiyet değişkeni bağlamında anlamlı bir farklılık olmadığı tespit edilmiştir. 
Tablo 13: Okul Yöneticilerinin Eğitim Örgütlerinde Yenilik Yönetimi Ölçeği Puanlarının Öğrenim Durumu Değişkenine Göre Mann Whitney U Testi Sonuçları

\begin{tabular}{|c|c|c|c|c|c|c|c|}
\hline Puanlar & Gruplar & $\mathbf{N}$ & $\overline{\mathbf{X}}_{\text {sira }}$ & Essra & $\mathbf{U}$ & $\mathbf{z}$ & $\mathbf{p}$ \\
\hline \multirow{3}{*}{ Girdi Yönetimi } & Lisans & 90 & 64,49 & 5804,50 & \multirow{3}{*}{1709,50} & \multirow{3}{*}{,- 887} & \multirow{3}{*}{,375 } \\
\hline & Lisansüstü & 42 & 7080 & 207350 & & & \\
\hline & Toplam & 132 & 10,80 & $29 / 3,50$ & & & \\
\hline \multirow{3}{*}{ Yenilik Stratejisi } & Lisans & 90 & 62,72 & 5645,00 & \multirow{3}{*}{1550,00} & \multirow{3}{*}{$-1,678$} & \multirow{3}{*}{,093 } \\
\hline & Lisansüstü & 42 & 7160 & 212300 & & & \\
\hline & Toplam & 132 & 14,60 & 3133,00 & & & \\
\hline \multirow{3}{*}{ Örgütsel Kültür ve Yapı } & Lisans & 90 & 65,30 & 5877,00 & \multirow{3}{*}{1782,00} & \multirow{3}{*}{,- 542} & \multirow{3}{*}{, 588} \\
\hline & Lisansüstü & 42 & 6907 & & & & \\
\hline & Toplam & 132 & $69,0 /$ & 2901,00 & & & \\
\hline \multirow{3}{*}{ Proje Yönetimi } & Lisans & 90 & 67,71 & 6093,50 & \multirow{3}{*}{1781,50} & \multirow{3}{*}{,- 536} & \multirow{3}{*}{,592 } \\
\hline & Lisansüstü & 42 & & & & & \\
\hline & Toplam & 132 & 63,92 & 2684,50 & & & \\
\hline \multirow{3}{*}{ Toplam } & Lisans & 90 & 65,11 & 5859,50 & \multirow{3}{*}{1764,50} & \multirow{3}{*}{,- 613} & \multirow{3}{*}{, 540} \\
\hline & Lisansüstü & 42 & 69.49 & 2918.50 & & & \\
\hline & Toplam & 132 & 69,49 & 2918,50 & & & \\
\hline
\end{tabular}

Tablo 13'e göre, okul yöneticilerinin eğitim örgütlerinde yenilik yönetimi ölçeği puanlarının öğrenim durumu değişkeni bağlamında anlamlı bir farklılık olmadığı tespit edilmiştir.

Tablo 14: Okul Yöneticilerinin Eğitim Örgütlerinde Yenilik Yönetimi Ölçeği Puanlarının Branş Değişkenine Göre Mann Whitney U Testi Sonuçları

\begin{tabular}{|c|c|c|c|c|c|c|c|}
\hline Puanlar & Gruplar & $\mathbf{N}$ & $\overline{\mathbf{X}}_{\text {sira }}$ & $\sum_{\text {ssra }}$ & $\mathbf{U}$ & $\mathbf{z}$ & $\mathbf{p}$ \\
\hline \multirow{3}{*}{ Girdi Yönetimi } & Sınıf Öğretmeni & 35 & 61,34 & 2147,00 & \multirow{3}{*}{1517,00} & \multirow{3}{*}{,- 936} & \multirow{3}{*}{,349 } \\
\hline & Branş Öğretmeni & 97 & & & & & \\
\hline & Toplam & 132 & 68,36 & 6631,00 & & & \\
\hline \multirow{3}{*}{ Yenilik Stratejisi } & Sınıf Öğretmeni & 35 & 63,66 & 2228,00 & \multirow{3}{*}{1598,00} & \multirow{3}{*}{,- 518} & \multirow{3}{*}{,604 } \\
\hline & Branş Öğretmeni & 97 & 6753 & 655000 & & & \\
\hline & Toplam & 132 & $0 /, 53$ & 0550,00 & & & \\
\hline \multirow{3}{*}{ Örgütsel Kültür ve Yap1 } & Sınıf Öğretmeni & 35 & 64,67 & 2263,50 & \multirow{3}{*}{1633,50} & \multirow{3}{*}{,- 339} & \multirow{3}{*}{, 734} \\
\hline & Branş Öğretmeni & 97 & & & & & \\
\hline & Toplam & 132 & $6 \%, 16$ & 6514,50 & & & \\
\hline \multirow{3}{*}{ Proje Yönetimi } & Sınıf Öğretmeni & 35 & 67,93 & 2377,50 & \multirow{3}{*}{1647,50} & \multirow{3}{*}{,- 261} & \multirow{3}{*}{,794 } \\
\hline & Branş Öğretmeni & 97 & 6508 & 640050 & & & \\
\hline & Toplam & 132 & 05,90 & 0400,30 & & & \\
\hline \multirow{3}{*}{ Toplam } & Sınıf Öğretmeni & 35 & 65,03 & 2276,00 & \multirow{3}{*}{1646,00} & \multirow{3}{*}{,- 266} & \multirow{3}{*}{,791 } \\
\hline & Branş Öğretmeni & 97 & 67,03 & 6502,00 & & & \\
\hline & Toplam & 132 & & & & & \\
\hline
\end{tabular}

Tablo 14'e göre, okul yöneticilerinin eğitim örgütlerinde yenilik yönetimi ölçeği puanlarının branş değişkeni bağlamında anlamlı bir farklılık olmadığı tespit edilmiştir. 
Tablo 15: Okul Yöneticilerinin Eğitim Örgütlerinde Yenilik Yönetimi Ölçeği Puanlarının Görev Yapılan Okul Türü Değişkenine Göre Kruskal Wallis Testi Sonuçları

\begin{tabular}{|c|c|c|c|c|c|c|}
\hline Puanlar & Gruplar & $\mathbf{N}$ & $\overline{\mathbf{X}}_{\text {sIra }}$ & sd & $\mathbf{X}^{2}$ & $\mathbf{p}$ \\
\hline \multirow{4}{*}{ Girdi Yönetimi } & İlkokul & 44 & 61,03 & \multirow{4}{*}{2} & \multirow{4}{*}{1,768} & \multirow{4}{*}{,413 } \\
\hline & Ortaokul & 48 & 71,58 & & & \\
\hline & Lise & 40 & 66,41 & & & \\
\hline & Toplam & 132 & & & & \\
\hline \multirow{4}{*}{ Yenilik Stratejisi } & İlkokul & 44 & 62,44 & \multirow{4}{*}{2} & \multirow{4}{*}{2,137} & \multirow{4}{*}{,344 } \\
\hline & Ortaokul & 48 & 72,85 & & & \\
\hline & Lise & 40 & 63,34 & & & \\
\hline & Toplam & 132 & & & & \\
\hline \multirow{4}{*}{ Örgütsel Kültür ve Yap1 } & İlkokul & 44 & 66,44 & \multirow{4}{*}{2} & \multirow{4}{*}{, 657} & \multirow{4}{*}{, 720} \\
\hline & Ortaokul & 48 & 63,59 & & & \\
\hline & Lise & 40 & 70,05 & & & \\
\hline & Toplam & 132 & & & & \\
\hline \multirow{4}{*}{ Proje Yönetimi } & İlkokul & 44 & 65,61 & \multirow{4}{*}{2} & \multirow{4}{*}{,060 } & \multirow{4}{*}{,970 } \\
\hline & Ortaokul & 48 & 67,51 & & & \\
\hline & Lise & 40 & 66,26 & & & \\
\hline & Toplam & 132 & & & & \\
\hline \multirow{4}{*}{ Toplam } & İlkokul & 44 & 64,23 & \multirow{4}{*}{2} & \multirow{4}{*}{,476 } & \multirow{4}{*}{,788 } \\
\hline & Ortaokul & 48 & 69,47 & & & \\
\hline & Lise & 40 & 65,44 & & & \\
\hline & Toplam & 132 & & & & \\
\hline
\end{tabular}

Tablo 15'e göre, okul yöneticilerinin eğitim örgütlerinde yenilik yönetimi ölçeği puanlarının görev yapılan okul türü değişkeni bağlamında anlamlı bir farklılık olmadığı tespit edilmiştir.

Tablo 16: Okul Yöneticilerinin Teknoloji Liderliği Stratejileri ile Yenilik Yönetimi Yeterlik Algıları Arasındaki Korelasyon

\begin{tabular}{|c|c|c|c|c|c|c|c|}
\hline & & $\begin{array}{c}\text { Teknoloji } \\
\text { Liderliği } \\
\text { Yeterlikleri }\end{array}$ & $\begin{array}{c}\text { Yenilik } \\
\text { Yönetimi } \\
\text { Yeterlikleri }\end{array}$ & $\begin{array}{c}\text { Girdi } \\
\text { Yönetimi }\end{array}$ & $\begin{array}{c}\text { Yenilik } \\
\text { Stratejisi }\end{array}$ & $\begin{array}{c}\text { Örgütsel } \\
\text { Kültür ve } \\
\text { Yapı }\end{array}$ & $\begin{array}{c}\text { Proje } \\
\text { Yönetimi }\end{array}$ \\
\hline Teknoloji & $r$ & & & & & & \\
\hline Liderliği & $p$ & . & & & & & \\
\hline Stratejileri & $N$ & 132 & & & & & \\
\hline Yenilik & $r$ &, $756 * *$ & & & & & \\
\hline Yönetimi & $p$ &, 000 & 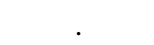 & & & & \\
\hline Yeterlikleri & $N$ & 132 & 132 & & & & \\
\hline \multirow{3}{*}{$\begin{array}{c}\text { Girdi } \\
\text { Yönetimi }\end{array}$} & $r$ & ,752** & ,844** & & & & \\
\hline & $p$ &, 000 &, 000 & & & & \\
\hline & $N$ & 132 & 132 & 132 & & & \\
\hline \multirow{3}{*}{$\begin{array}{l}\text { Yenilik } \\
\text { Stratejisi }\end{array}$} & $r$ & ,668** &, $868 * *$ &, $686^{* * *}$ & & & \\
\hline & $p$ &, 000 &, 000 & ,000 & . & & \\
\hline & $N$ & 132 & 132 & 132 & 132 & & \\
\hline \multirow{3}{*}{$\begin{array}{c}\text { Örgütsel } \\
\text { Kültür ve } \\
\text { Yap1 }\end{array}$} & $r$ &, $596 * *$ &, $838 * *$ &, $601 * *$ &, $668 * *$ & & \\
\hline & $p$ &, 000 &, 000 &, 000 &, 000 & . & \\
\hline & $N$ & 132 & 132 & 132 & 132 & 132 & \\
\hline \multirow{3}{*}{$\begin{array}{c}\text { Proje } \\
\text { Yönetimi }\end{array}$} & $r$ & ,636** & ,894** &, $653 * *$ & ,678** &, $763 * *$ & \\
\hline & $p$ & ,000 &, 000 &, 000 &, 000 &, 000 & 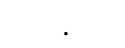 \\
\hline & $N$ & 132 & 132 & 132 & 132 & 132 & 132 \\
\hline
\end{tabular}

Spearman korelasyonu kapsamında araştırmanın bağımlı ve bağımsız değişkenleri arasındaki ilişki analiz edilmiştir. Bu bağlamda, bağımlı ve bağımsız değişkenler arasındaki korelasyon ilişkileri değerlendirilmiştir; r İlişki; 0.00-0.25 Çok Zayıf, 0.26-0.49 Zayıf, 0.50-0.69 Orta, 0.70-0.89 Yüksek, 0.90-1.00 Çok Yüksek, şeklinde yorumlanmıştır (Özdamar, 2002). 
Tablo 16' da görüldüğü üzere eğitim kurumu yöneticilerinin teknoloji liderliği yeterlik algıları ile yenilik yönetimi yeterlikleri arasında pozitif yönde ve yüksek düzeyde korelasyon tespit edilmiştir $(\mathrm{r}=0.756 \mathrm{p}<.01)$.

$\mathrm{Bu}$ bağlamda okul yöneticilerinin teknoloji liderliği stratejileri ile yenilik yönetimi yeterlikleri arasında toplam ve tüm alt boyutlarda anlamlı bir ilişki olduğu sonucuna varılmıştır.

Buna göre öncelikle teknoloji liderliği stratejileri ile girdi yönetimi $(\mathrm{r}=0.752 ; \mathrm{p}<.01)$ alt boyutu arasında pozitif yönde ve yüksek düzeyde ilişki olduğu görülmektedir. Ayrıca yenilik stratejisi $(\mathrm{r}=0.668 ; \mathrm{p}<.01)$, örgütsel kültür ve yapr $(\mathrm{r}=0.596 ; \mathrm{p}<.01)$, proje yönetimi $(\mathrm{r}=0.636 ; \mathrm{p}<.01)$ alt boyutları ile teknoloji liderliği stratejileri arasında pozitif yönde ve orta düzeyde ilişki olduğu görülmektedir.

Tablo 17: Okul Yöneticilerinin Yenilik Yönetimi Yeterlik Algıları ile Teknoloji Liderliği Stratejileri Arasındaki Korelasyon

\begin{tabular}{|c|c|c|c|c|c|c|c|c|}
\hline & & $\begin{array}{c}\text { Yenilik } \\
\text { Yönetimi } \\
\text { Yeterlikleri }\end{array}$ & $\begin{array}{c}\text { Teknoloji } \\
\text { Liderliği } \\
\text { Yeterlikleri }\end{array}$ & $\begin{array}{l}\text { Vizyoner } \\
\text { Liderlik }\end{array}$ & $\begin{array}{c}\text { Dijital } \\
\text { Çağ } \\
\text { Öğrenme } \\
\text { Külttürü } \\
\end{array}$ & $\begin{array}{c}\text { Profesyonel } \\
\text { Uygulamada } \\
\text { Mükemmellik }\end{array}$ & $\begin{array}{l}\text { Sistematik } \\
\text { Gelişim }\end{array}$ & $\begin{array}{c}\text { Dijital } \\
\text { Vatandaşl1k }\end{array}$ \\
\hline Yenilik & $r$ & & & & & & & \\
\hline Yönetimi & $p$ & . & & & & & & \\
\hline Yeterlikleri & $N$ & 132 & & & & & & \\
\hline Teknoloji & $r$ &, $756 * *$ & & & & & & \\
\hline Liderliği & $p$ &, 000 & . & & & & & \\
\hline Stratejileri & $N$ & 132 & 132 & & & & & \\
\hline \multirow{3}{*}{$\begin{array}{l}\text { Vizyoner } \\
\text { Liderlik }\end{array}$} & $r$ & ,639** &, $820 * *$ & & & & & \\
\hline & $p$ &, 000 &, 000 & $\cdot$ & & & & \\
\hline & $N$ & 132 & 132 & 132 & & & & \\
\hline \multirow{3}{*}{$\begin{array}{l}\text { Dijital Çağ } \\
\text { Öğrenme } \\
\text { Kültürü }\end{array}$} & $r$ & ,677** & ,907** & ,735** & & & & \\
\hline & $p$ &, 000 &, 000 &, 000 & . & & & \\
\hline & $N$ & 132 & 132 & 132 & 132 & & & \\
\hline \multirow{3}{*}{$\begin{array}{l}\text { Profesyonel } \\
\text { Uygulamada } \\
\text { Mükemmellik }\end{array}$} & $r$ &, $707 * *$ &, $849 * *$ &, $687 * *$ &, $840 * *$ & & & \\
\hline & $p$ & ,000 &, 000 &, 000 &, 000 & . & & \\
\hline & $N$ & 132 & 132 & 132 & 132 & 132 & & \\
\hline \multirow{3}{*}{$\begin{array}{l}\text { Sistematik } \\
\text { Gelişim }\end{array}$} & $r$ &, $630 * *$ &, $843 * *$ &, $628 * *$ &, $725 * *$ &, $660 * *$ & & \\
\hline & $p$ &, 000 &, 000 &, 000 &, 000 &, 000 & & \\
\hline & $N$ & 132 & 132 & 132 & 132 & 132 & 132 & \\
\hline \multirow{3}{*}{$\begin{array}{c}\text { Dijital } \\
\text { Vatandaşlık }\end{array}$} & $r$ &, $729 * *$ &, $832 * *$ & ,644** & ,643** & ,657** & ,676** & \\
\hline & $p$ & 000 &, 000 &, 000 &, 000 &, 000 &, 000 & . \\
\hline & $N$ & 132 & 132 & 132 & 132 & 132 & 132 & 132 \\
\hline
\end{tabular}

**. Korelasyon anlaml1lık düzeyi 0.01 level (2-tailed).

Tablo 17 'de görüldüğü gibi eğitim kurumu yöneticilerinin yenilik yönetimi yeterlikleri ile teknoloji liderliği yeterlik algıları arasında pozitif yönde ve yüksek düzeyde korelasyon tespit edilmiştir ( $\mathrm{r}=0.756 \mathrm{p}<.01)$. Bu bağlamda, okul yöneticilerinin yenilik yönetimi yeterlikleri ile teknoloji liderliği yeterlikleri arasında toplam ve tüm alt boyutlarda anlamlı bir ilişki olduğu sonucuna varılmıştır.

Buna göre öncelikle yenilik yönetimi ile profesyonel uygulamada mükemmellik $(\mathrm{r}=0.707 ; \mathrm{p}<.01)$, dijital vatandaşlık $(\mathrm{r}=0.729 ; \mathrm{p}<.01)$ alt boyutları arasında pozitif yönde ve yüksek düzeyde ilişki olduğu görülmektedir. Ayrıca vizyoner liderlik ( $\mathrm{r}=0.639 ; \mathrm{p}<.01)$, dijital çă̆ öğrenme kültürü $(\mathrm{r}=0.677 ; \mathrm{p}<.01)$, sistematik gelişim $(\mathrm{r}=0.630 ; \mathrm{p}<.01)$ alt boyutları ile yenilik yönetimi algıları arasında pozitif yönde ve orta düzeyde ilişki olduğu görülmektedir.

\section{Sonuç, Tartışma ve Öneriler}

Araştırmada, teknoloji liderliği ölçeğine göre okul yöneticilerinin kendilerini genellikle yeterli ( $\overline{\mathrm{X}}$ : 3.94) gördükleri sonucuna varılmıştır. 
Bu çalışmanın sonucunu destekler nitelikte, aynı ölçme aracını kullanan Bülbül ve Çuhadar (2012) yaptıkları araştırma sonucunda teknoloji liderliği ölçeğine göre okul yöneticilerinin kendilerini genellikle yeterli algıladıklarını ortaya koymuştur. Benzer bir şekilde, Banoğlu (2011) okul yöneticilerinin teknoloji liderliği yeterliklerini belirlemek amacıyla yaptı̆ğ çalışma sonuçlarına göre, çalışmaya katılan yöneticilerin teknoloji liderliği yeterliğine sahip olduğu sonucuna ulaşmıştır.

Araştırmada, okul yöneticilerinin yenilik yönetimi yeterlik algılarının çok yeterli $(\overline{\mathrm{X}}: 4.23)$ olduğu sonucuna varılmıştır.

$\mathrm{Bu}$ çalışmanın sonucunu destekler nitelikte, aynı ölçme aracını kullanan Bülbül (2012b) okul yöneticilerinin yenilik yönetimi yeterlik algılarına göre tamamen katıllyorum düzeyine karşıllık geldiği sonucuna ulaşmıştır.

Okul yöneticilerinin teknoloji liderliği yeterliklerine yönelik alt boyutlardan Profesyonel uygulamada mükemmellik boyutunun en yüksek puana sahip olduğu, bunu Vizyoner liderlik alt boyutu, Dijital çağ öğrenme kültürü alt boyutu, Sistematik gelişim alt boyutu ve en son olarak "Dijital vatandaşlık" boyutlarının izlediği sonucuna ulaşılmıştır.

Alanyazın incelendiğinde, Gültekin (2013) yaptığı çalışma sonucunda ise teknoloji liderliği ölçeğine göre okul yöneticilerinin en fazla Vizyoner Liderlik alt boyutunda yeterli algıladıklarını, daha sonra ise Profesyonel Uygulamada Mükemmellik alt boyutu, Dijital Vatandaşlık alt boyutu, Dijital Çağ Öğrenme Kültürü alt boyutu ve Sistematik Gelişim alt boyutunun geldiği sonucuna ulaşmıştır.

Yenilik yönetimi yeterliklerine yönelik alt boyutlardan Proje Yönetimi boyutunun en yüksek puana sahip olduğu, bunu Örgütsel Kültür ve Yapı, Yenilik Stratejisi ve en son olarak Girdi Yönetimi boyutlarının izlediği tespit edilmiştir.

Bu bulgularla paralellik gösterecek bir şekilde, okullarda yenilik yönetimi ölçeğine yönelik yönetici algılarını belirmeye çalışan Bülbül (2012b) ve öğretmenlerin müdürlerine yönelik algılarını ortaya koymaya çalışan Öztürk’ün (2017) yaptığı araştırma sonucuna göre Örgütsel Kültür ve Yapı alt boyutunda en fazla, ardından Proje Yönetimi, Yenilik Stratejisi ve Girdi Yönetimi boyutu olduğu sonucuna ulaşılmıştır. Ayrıca Esen (2016), öğretmenlerin müdürlerine yönelik algılarını belirlemek amaciyla yaptığı çalışmanın sonucuna göre Proje Yönetimi alt boyutu, Yenilik Stratejisi, Örgütsel Kültür ve Yapı ve en son Girdi Yönetimi boyutu olduğu sonucuna ulaşılmıştır. Göl ve Bülbül (2012) ile Gök ve Özçetin (2015) ise çalışmalarında öğretmenlerin algılarına göre, okul yöneticileri en fazla Yenilik Stratejisi, Örgütsel Kültür ve Yapı alt boyutu, Proje Yönetimi alt boyutu ve en düşük düzeyde Girdi Yönetimi alt boyutunda yeterli olarak algılamaktadırlar.

Alanyazın incelendiğinde, okul yöneticilerinin hem öğretmen hem de yönetici algılarına göre girdi yönetimi boyutunda daha az yeterli olarak algılandıkları söylenebilir. Bu bağlamda, okul yöneticilerinin, eğitim yönetimi alanında yeterlik sahibi ve uzmanlardan destek alması, değişim ve yenilik sürecinin başarılı olması için kamu ve özel kurum ve kuruluşlarla iş birliği halinde çalışarak eğitim kurumu için gerekli ekipman ve donanım malzemelerinin sağlanması konularına daha fazla önem vermeleri gerektiği vurgulanabilir.

$\mathrm{Bu}$ çalışmada, eğitim kurumu yöneticilerinin yenilik yönetimi ve teknoloji liderliği ölçeğine göre öz-yeterlik algıları, cinsiyet, branş, öğrenim durumu ve okul türüne göre anlamlı bir fark tespit edilememişken; görev unvanı ve bilişim teknolojileri alanında hizmet içi eğitim almış olma değişkeni bağlamında anlamlı bir farklılık olduğu sonucuna ulaşılmıştır. Bu bağlamda, teknoloji liderliği ve yenilik yönetimi yeterlik ölçeğine göre okul müdürlerinin puan ortalamaları, müdür yardımcılarından anlamlı seviyede daha yüksektir. Devlet okullarında görev yapan eğitim kurumu yöneticilerinden hizmet içi eğitim almış olanların puan ortalamalar ise bu alanda eğitim almayanlara göre göre anlamlı seviyede daha yüksek olduğu ortaya konulmuştur. $\mathrm{Bu}$ bulguyu destekler nitelikte, okul yöneticilerinin teknoloji liderliği stratejileri ile yenilik yönetimi yeterlik inançları arasındaki ilişkinin 
tespit edilmesi amacıyla yapılan çalışmaya göre, eğitim kurumu yöneticilerinin yenilik yönetimi ve teknoloji liderliği ölçeğine göre bilişim teknolojileri alanında hizmet içi eğitim alma değişkeni bağlamında anlamlı bir fark tespit edilmiş̧ir. (Demiraçan, 2019). Alanyazın incelendiğinde, Bülbül ve Çuhadar (2012); Gün ve Çoban (2019) yılında yapmış oldukları Okul Yöneticilerinin Teknolojik Liderliği Öz Yeterliklerine yönelik çalışmaların sonuçlarına göre de cinsiyet, kurum türü ve öğrenim durumu değişkenleri bağlamında anlamlı bir fark bulunmamıştır.

Araştırmada okul yöneticilerinin algısına göre yenilik yönetimi ile teknoloji liderliği yeterlikleri arasında yüksek seviyede ve pozitif yönlü bir korelasyon olduğu sonucuna ulaşılmıştır. Eğitim kurumu yöneticilerinin yenilik yönetimi algıları ile teknoloji liderliği yeterliklerinin tüm alt boyutları arasında belirli bir korelasyon olduğu tespit edilmiştir. Bu bağlamda, yenilik yönetimi ile profesyonel uygulamada mükemmellik alt boyutları ve dijital vatandaşlık arasında pozitif yönlü ve yüksek düzeyde korelasyon tespit edilmiştir. Bununla birlikte, vizyoner liderlik alt boyutu, dijital çağ öğrenme kültürü alt boyutu ve sistematik gelişim alt boyutları ile yenilik yönetimi algıları arasında pozitif yönlü ve orta seviyede korelasyon olduğu sonucuna ulaşılmıştır. Alanyazın incelendiğinde, bu araştırmaya benzer şekilde, okul yöneticilerinin teknoloji liderliği stratejileri ile yenilik yönetimi yeterlik inançları arasında pozitif yönlü ve orta seviyede bir korelasyon olduğu sonucuna ulaşılmıştır (Demiraçan, 2019). Bunun yanında, Esen (2016) yılında yapmış olduğu çalışmanın sonucuna göre öğretmenlerin görüşlerine göre eğitim kurumu yöneticilerinin liderlik stilleri ile yenilik yönetimi puan ortalamaları arasında pozitif yönlü ve yüksek seviyede bir korelasyon olduğunu ortaya koymuştur.

Okul yöneticilerinin teknoloji liderliği algıları ile yenilik yönetimi yeterliklerinin tüm alt boyutları arasında belirli bir korelasyon olduğu tespit edilmiştir. Buna göre, teknoloji liderliği yeterlikleri ile girdi yönetimi alt boyutu arasında pozitif yönlü ve yüksek seviyede bir korelasyon olduğu sonucuna ulaşılmıştır. Ayrıca, yenilik stratejisi, örgütsel kültür ve yapı ve proje yönetimi alt boyutları ile teknoloji liderliği yeterlikleri arasında pozitif yönlü ve orta seviyede bir korelasyon tespit edilmiştir.

Alanyazın incelendiğinde, bu çalışmanın sonuçlarına paralel olarak, Millî Eğitim Şurasında alınan kararlar ile MEB 2023 Eğitim Vizyon Belgesinde yer alan yönetici atama ve yetiştirilmesine yönelik hedefler bu doğrultuda bir yol haritası ortaya koymaktadır (MEB, 2018a, 2019a, 2019b).

$\mathrm{Bu}$ bağlamda, okul yöneticilerinin atanması ve yetiştirilmesi kapsamında, uluslararası düzeyde gelişmiş ülkelerde lisansüstü eğitim yani yüksek lisans ve doktora dereceleri oldukça önemlidir. İl ve ilçe düzeyinde eğitim yöneticiliği için yönetim alanında doktora dereceleri gerekli olmaktadır. Ayrıca, okul yöneticiliği için yetiştirme programları uygulama ağırlıklı olarak yapılmaktadır (Aypay, 2016: 2).

Mevcut okul yöneticilerinin kişisel ve mesleki gelişimleri açısından, üniversiteler ile MEB'nın koordineli bir şekilde çalışmasının önemi belirtilmektedir. Bu bağlamda, yüz yüze veya uzaktan eğitim yoluyla iş birliklerinin hayata geçirilmesinin faydalı olacağı düşünülmektedir. (MEB, 2019a, 2019b).

\section{Öneriler}

Milli Eğitim Bakanlığının hazırlamış olduğu 2023 Eğitim Vizyonu Belgesi’nin başarılı olabilmesi, eğitim kurumlarında yer alan aktörler tarafından doğru algılanmasına bağlıdır. $\mathrm{Bu}$ bağlamda 2023 Eğitim Vizyonu Belgesi'nde yer alan eğitim kurumu yöneticileri için yapılan bazı hizmet içi eğitim faaliyetlerinin katılıma dayalı belge alma uygulamasının yerine üniversitelerle iş birliğine gidilerek akredite sertifika programları olarak dönüştürülmesi önerilir. MEB ile Üniversiteler arasında hizmet içi eğitimler kapsamında iş birliği yapılmasının faydalı olacağı düşünülmektedir. Ayrıca 2023 Eğitim Vizyonu Belgesi'nde belirtilen, eğitim kurumu yöneticilerinin 
mesleki gelişimlerinin sürekli desteklemesi amacıyla üniversiteler ile ve STK'larla yüz yüze, örgün ve/veya uzaktan öğretim iş birliklerinin hayata geçirilmesi önerilir.

Eğitimin niteliğinin arttırılması için okul yöneticilerinin teknoloji liderliği ve yenilik yönetimi yeterliklerine ilişkin olarak sadece yönetici algılarına göre değil aynı zamanda eğitim kurumlarında yer alan tüm aktörleri kapsayan bir şekilde analiz edilmesinin alanyazına katkı sağlayacağı düşünülmektedir. Bu araştırma, nicel araştırma yöntemi ile yapılmış olup, bu bağlamda derinlemesine analiz yapılması amacıyla nitel bir çalışma yapılabilir.

\section{Kaynakça}

Afshari, M., Bakar, K. A., Luan, W. S., Samah, B. A., \& Fooi, F. S. (2009). Technology and school leadership. Technology, Pedagogy and Education,18(2), 235-248. https://doi.org/10.1080/14759390902992527

Akbaba-Altun, S., \& Gürer, M. D. (2008). School administrators' perceptions of their roles regarding information technology classrooms. Eurasian Journal of Educational Research (EJER), 33, $35-54$.

Anderson, R. E., \& Dexter, S. (2005). School technology leadership: An empirical investigation of prevalence and effect. Educational Administration Quarterly, 41, 49-82. https://doi.org/10.1177/0013161X04269517

Argon, T., İsmetoğlu, M. \& İşeri, B., (2015). “Okul yöneticilerinin değerlere göre yönetim ile yenilik yönetimlerine yönelik öğretmen görüşleri”. Ĕgitim ve Öğretim Araştırmaları Dergisi, 3(4), 111-119.

Aydoğar, N. (2018). Okul yöneticilerinin yenilik yönetimi becerilerinin öğretmen görüşlerine göre incelenmesi. Kahramanmaraş il merkezi özel ve devlet okulları örneği. [Yüksek lisans tezi], Kahramanmaraş Sütçü İmam Üniversitesi.

Aypay, A. (2016). Türkiye'de eğitim yöneticiliği ve maarif müfettişliği: seçme, atama ve yetiştirme içinde eğitim yönetimi ve denetimi alanının durumu ve geleceği. Pegem Akademi.

Banoğlu, K. (2011). Okul müdürlerinin teknoloji liderliği yeterlikleri ve teknoloji koordinatörlüğü. Kuram ve Uygulamada Eğitim Bilimleri, 11(1), 199-213.

Boydak, O. M. \& Karabatak, S. (2013). "Ortaöğretim okul yöneticilerinin yenilik yönetimine yaklaşımları ve karşılaştıkları sorunlar". International Online Journal of Educational Sciences, 5(1), 258-273.

Bursalığlu, Z. (2012). Okul yönetiminde yeni yapı ve davranış. Pegem Akademi.

Bülbül, T. (2012a). Okullarda Yenilik Yönetimi Ölçeği'nin geliştirilmesi: geçerlik ve güvenirlik çalışmas1. Kuram ve Uygulamada Eğitim Bilimleri, 12(1), 157-175.

Bülbül, T. (2012b). Okul yöneticilerinin yenilik yönetimine ilişkin yeterlik inançları. Trakya Üniversitesi Sosyal Bilimler Dergisi, 14(1), 45-68.

Bülbül, T. (2017). Yenilik yönetimi. Memduhoğlu, H.B. \& Yılmaz, K. (Ed.), Yönetimde yeni yaklaşımlar içinde (s. 43-72). Pegem Akademi.

Bülbül, T., \& Çuhadar, C. (2012). Okul yöneticilerinin teknoloji liderliği öz-yeterlik algıları ile bilgi ve iletişim teknolojilerine yönelik kabulleri arasındaki ilişkinin incelenmesi. Mehmet Akif Ersoy Üniversitesi Ĕ̈itim Fakültesi Dergisi, 12(23), 479-499.

Can, T. (2003). Bolu orta öğretim okulları yöneticilerinin teknolojik liderlik yeterlilikleri. The Turkish Online Journal of Educational Technology, 2(3), 94-107. 
Can, T. (2008). İlköğretim okulları yöneticilerinin teknolojik liderlik yeterlilikleri. 8.Uluslararası Eğitim Teknolojileri Konferansı, 6-9 Mayls 2008 (s. 1053-1057). Anadolu Üniversitesi.

Cormican, K., \& O'Sullivan, D. (2004). Auditing best practice for effective product innovation management, Technovation, 24, 819-829. https://doi.org/10.1016/S0166-4972(03)00013-0

Çobanoğlu, F., \& Badavan, Y. (2017). Başarılı okulun anahtarı: Etkili okul değişkenleri. Pamukkale Üniversitesi Sosyal Bilimler Enstitüsü Dergisi, 114-134.

Demiraçan, A. (2019). Okul yöneticilerinin teknoloji liderliği stratejileri ile yenilik yönetimi yeterlik inançları arasındaki iliş̧kinin incelenmesi. [Yüksek lisans tezi], Trakya Üniversitesi.

Esen, F. (2016). Okul öncesi eğitim öğretmenlerinin algılarına göre okul müdürlerinin liderlik stilleri ile yenilik yönetimi arasındaki ilişki. [Yüksek lisans tezi], İstanbul Aydın Üniversitesi ve Yıldız Teknik Üniversitesi.

Gliem, J. A. \& Gliem, R. R. (2003). Calculating, interpreting and reporting Cronbach's alpha reliability coefficient for likert-type scales. Midwest Research to Practice Conference in Adult, Continuing, and Community Education, 82-88.

Göl, E. \& Bülbül, T. (2012). İlköğretim okul yöneticilerinin yenilik yönetimi yeterliklerine ilişkin öğretmen algıları (Kırklareli ili örneği), Mersin Üniversitesi Eğitim Fakültesi Dergisi, 8(2), 97-109.

Görgel, H. M. (2018). Okul yöneticilerinin yenilik yönetimi yeterliklerine ilişkin ögretmen ve okul yöneticisi algılarının incelenmesi. [Yüksek lisans tezi], Kahramanmaraş Sütçü İmam Üniversitesi.

Güçlü, N. (2016). Liderliğe genel bir bakış. N. Güçlü \& S. Koşar (Ed.), Eğitim yönetiminde liderlik teori, araştırma ve uygulama içinde (s. 1-16). Pegem Akademi.

Güçlü, N. \& Koşar, S. (Ed.). (2016). Eğitim yönetiminde liderlik: teori, araştırma ve uygulama. Pegem Akademi.

Gültekin, F. (2013). Ortaöğretim yöneticilerinin teknoloji liderliği-öz-yeterlik algıları. [Yüksek lisans tezi], Marmara Üniversitesi.

Gümüşeli, A. İ. (2001). Çağdaş okul müdürlerinin liderlik alanları. Kuram ve Uygulamada Eğitim Yönetimi Dergisi, 28, 531-548.

Gümüşeli, A. İ. (2014). Ĕgitim ve ögretim yönetimi: eğitim programı ve ögretimi yönetme, öğrenci ilerlemesini izleme, öğretmenleri denetleme ve değerlendirme. Pegem Akademi.

Gün, F. \& Çoban, Ö. (2019). Okul yöneticilerinin teknolojik liderlik öz yeterliklerinin incelenmesi. Uluslararası Karamanoğlu Mehmetbey Ĕ̆itim Araştırmaları Dergisi, 39-48.

Günbay1, İ. (2016). Liderlik ve toplumsal değişme. N. Güçlü ve S. Koşar (Ed.), Eğitim yönetiminde liderlik teori, araştırma ve uygulama içinde (s. 245-282). Pegem Akademi.

Hacıfazlığlu, Ö. (2016). Yaratıcılık, inovasyon ve okul liderliği. N. Güçlü ve S. Koşar (Ed.), Eğitim yönetiminde liderlik teori, araştırma ve uygulama içinde (s. 283- 322). Pegem Akademi.

Hacıfazlıŏlu, Ö., Karadeniz, Ş. \& Dalgıç, G. (2011a). Eğitim yöneticileri teknoloji liderliği özyeterlik ölçeğinin geçerlik ve güvenirlik çalışması. Kuram ve Uygulamada Eğitim Yönetimi, $17(2), 145-166$.

Hacıfazlığlu, Ö., Karadeniz, Ş. \& Dalgıç, G. (2010). Eğitim yöneticileri teknoloji liderliği standartlarına ilişkin öğretmen, yönetici ve denetmenlerin görüşleri. Kuram ve Uygulamada Ĕ̈itim Yönetimi, 16(4), 537-577. 
Hacıfazlığlu, Ö., Karadeniz, Ş. \& Dalgıç, G. (2011b). Okul yöneticilerinin teknoloji liderliğine ilişkin algıları: metafor analizi örneği [School administrators' perceptions of technology leadership: an example for metaphor analysis]. Eğitim Bilimleri Araştırmaları Dergisi, 1(1), 97-121.

ISTE. (2002). NETS for administrators 2002. http://www.iste.org/Content/NavigationMenu/NETS/ ForAdministrators/2002Standards/NETS_for_Administrators_2002_Standards.htm Erişim Tarihi: 17.06.2020.

ISTE. (2009). NETS for administrators 2009. http://www.iste.org/Content/NavigationMenu/ETS/ ForAdministrators/2009Standards/NETS_for_Administrators_2009.htm Erişim Tarihi: 17.06.2020.

Karaca, B. (2019). Okul yöneticilerinden ilkokul müdürlerinin yenilik yönetimi yeterliliklerine ilişkin ögretmen algıları: İstanbul ili Beykoz ilçesi örneği. [Yüksek lisans tezi], Beykent Üniversitesi.

Karasar, N. (2016). Bilimsel araştırma yöntemleri: kavramlar, ilkeler, teknikler. Nobel Yayın.

Karataş, S., Gök, R. \& Özçetin, S. (2015). "Okul yöneticilerinin yenilik yönetimi yeterliklerine ilişkin öğretmen algıları”, Mehmet Akif Ersoy Üniversitesi Ĕ̈itim Fakültesi Dergisi, 33(1), 167-185.

Koçel, T. (2018). Işsletme yöneticiliği: yönetim ve organizasyon, organizasyonlarda davranış, klasik, modern, çağdaş ve güncel yaklaşımlar. Genişletilmiş 17. Baskı. Beta Yayınları.

Lin, Nan. (1976). Foundations of social research. Mc Graw-Hill.

MEB. (2018a). Türkiye 2023 Ë̆itim Vizyonu. http://2023vizyonu.meb.gov.tr/doc/2023_EGITIM_ VIZYONU.pdf Erișim Tarihi: 12.12.2020.

MEB. (2018b). Turkey's Education Vision 2023. https://2023vizyonu.meb.gov.tr/doc/2023_VIZ YON_ENG.pdf Erişim Tarihi: 12.12.2020.

MEB. (2019a). XVIII. MEB Şurasında alınan kararlar. MEB Şura Kararlarl, 2010. http://ttkb.meb. gov.tr/meb_iys_dosyalar/2017_09/29170222_18_sura.pdf Erişim Tarihi: 12.12.2020.

MEB. (2019b). XIX. MEB Şurasında alınan kararlar. MEB Şura Kararları, 2014. http://mebk12. meb.gov.tr/meb_iys_dosyalar/35/27/719973/dosyalar/2015_02/02041116_19.millieitimura skararlar.pdf Erişim Tarihi: 12.12.2020.

MEB. (2020). http://fatihprojesi.meb.gov.tr/ Erişim Tarihi: 12.12.2020.

Oke, A. (2004). "Barriers to innovation management in service companies". Journal of Change Management, 4(1), 31- 44. https://doi.org/10.1080/1469701032000154953

Ömür, Y. E. (2014). "Lise yöneticilerinin yenilik yönetimi becerileri ile okullardaki örgütsel ögrenme mekanizmalarına yönelik ögretmen görüssleri”, [Yüksek lisans tezi], Abant İzzet Baysal Üniversitesi.

Özdamar, K. (2002). Paket programlar ile istatistiksel veri analizi 1. Kaan Kitabevi.

Özdemir, S. \& Kılınç, A. Ç. (2013). Değişen toplum ve okul. S. Özdemir (Ed.), Türk Eğitim Sistemi ve okul yönetimi içinde (s. 75-92). Pegem Akademi.

Öztürk, M., (2017). Illkokul müdürlerinin yenilik yönetimi yeterliklerine ilişkin öğretmen algıları: İstanbul ili Avcılar ilçesi örneği. [Yüksek lisans tezi], İstanbul Aydın Üniversitesi ve Yıldız Teknik Üniversitesi. 
Sincar, M. (2009). İlkögretim okulu yöneticilerinin teknoloji liderliği rollerine ilişskin bir inceleme (Gaziantep ili örneği). [Doktora tezi], İnönü Üniversitesi.

Sincar, M. \& Aslan, B. (2011). İlköğretim öğretmenlerinin okul yöneticilerinin teknoloji liderliği rollerine ilişkin görüşleri. Gaziantep Üniversitesi Sosyal Bilimler Dergisi, 10(1), 571-595.

Smith, M., Busi, M., Ball, P. \& Meer, R. (2008). "Factors influencing an organisations ability to manage innovation: a structured literature review and conceptual model", International Journal of Innovation Management, 12(4), 655-676. https://doi.org/10.1142/S1363919608002138

Şişman, M. (2012). Öğretim liderliği. Pegem Akademi.

Tabachnick, B. G. \& Fidell, L. S. (2013). Using multivariate statistics. (sixth ed.) Pearson.

Top, Z. (2011). Illköğretim okulu yöneticilerinin yenilik yönetimine ilişkin tutumlarının incelenmesi. [Yayımlanmamış doktora tezi], Marmara Üniversitesi.

Vlok, A. (2012). "A leadership competency profile for innovation leaders in a science-based research and innovation organization in South Africa", Procedia-Social and Behavioral Sciences, 41, 209-226. https://doi.org/10.1016/j.sbspro.2012.04.025

Yu, C., \& Durrington, V.A. (2006). Technology standards for school administrators: An analysis of practicing and aspiring administrators' perceived ability to performance standards. NASSP Bulletin, 90, 301-317. https://doi.org/10.1177/0192636506295392

\section{Beyan ve Açılamalar (Disclosure Statements)}

1. Araştırmacıların katk1 oranı beyanı/ Contribution rate statement of researchers: Birinci Yazar/First Author Dr. Baran Barış YILDIZ \%50, İkinci Yazar/ Second Author Dr. Harun TÜYSÜZ \%30, Üçüncü Yazar/Third Author Uzman Mustafa ÖZTÜRK \%20.

2. Yazarlar tarafından herhangi bir çıkar çatışması beyan edilmemiştir (No potential conflict of interest was reported by the authors). 